\title{
Productivity regime and phytoplankton size structure in the tropical and subtropical North Atlantic in spring 1989
}

\author{
Frank J. JOCHEM* ${ }^{*}$ and BerNT ZeITZSCheL ${ }^{*}$
}

(Received 13 September 1991: in revised form 18 . March 1992; accepted 23 March 1992)

\begin{abstract}
Productivity regime and phytoplankton size structure are described for two different epipelagic systems in the tropical/subtropical Northeast Atlantic Ocean investigated during 9-11 day drift studies in spring 1989 in the JGOFS North Atlantic Bloom Experiment. $18^{\circ} \mathrm{N}, 30^{\circ} \mathrm{W}$ and $33^{\circ} \mathrm{N}, 20^{\circ} \mathrm{W}$. At the $18^{\circ} \mathrm{N}$ study site, an oligotrophic system was encountered. The water column above the main pycnocline at about 50-60 $\mathrm{m}$ depth was nutrient-depleted, and both chlorophyll and primary production displayed subsurface maxima at the nutricline. Picoplankton was the dominant size fraction, accounting for $78-90 \%$ of chlorophyll and $83-98 \%$ of primary production. Synechococcus-type coccoid cyanobacteria were the dominant picoplankters. The hydrographic situation was characterized by high small-scale variability; the most interesting feature was the intrusion of nutrient-depleted Subtropical Salinity Maximum Water into the euphotic zone. whose impacts on the productivity regime are discussed. At $33^{\circ} \mathrm{N}$ study site, a post-bloom situation was encountered. Although the euphotic zone was nutrient-depleted, higher amounts of larger phytoplankton were present, the contribution of picoplankton being $42-53 \%$ of chlorophyll and $42-86 \%$ of primary production. Over the course of the drift study, subsurface maxima of chlorophyll and productivity evolved, the contribution of picoplankton having increased. Picocyanobacteria again were the dominant picoplankters. At both study sites the profiles of abundance ratios of picocyanobacteria to picoeucaryotes cell numbers proved to be a useful tool to characterize water masses.
\end{abstract}

\section{INTRODUCTION}

WITHIN the discussion of global climate change and increasing atmospheric carbon dioxide, the vertical flux of particulate carbon from the sea surface towards the deep sea and the ocean's role as a sink for atmospheric $\mathrm{CO}_{2}$ is of increasing interest. Other than inorganically bound carbon dioxide, the primary fixation of $\mathrm{CO}_{2}$ by algal photosynthesis is the main process to entrain free $\mathrm{CO}_{2}$ into the particulate phase and provide its access to vertical transport via sedimentation. The fate of primary bound $\mathrm{CO}_{2}$, i.e. of algal biomass, specifically whether it will sediment out of, or remain within the productive surface layer, depends on the physico-chemical properties of the epipelagic system and the modification of primary fixed organic carbon related to the food web structure of the respective ecosystem.

Biogenic sedimentation may occur as algal cells and/or cell constituents (shells, frustles, broken cells), predominant at the end of phytoplankton blooms when nutrients become growth-limiting and the zooplankton standing stock is insufficient to consume the phytoplankton biomass (SMETACEK et al., 1984). or as fecal pellets as a result of zooplankton activity.

\footnotetext{
*Institut für Meereskunde an der Universität Kiel, Düsternbrooker Weg 20, 2300 Kiel, Germany
} 
Direct sedimentation of algal cells will be highly dependent on the size structure of the phytoplankton assemblage (BIENFANG, 1981) since, according to Stoke's Law, mainly larger cells in the microplankton $(>20 \mu \mathrm{m})$ size range are expected to sink. Sedimentation rates of picoplankton $(<2 \mu \mathrm{m})$ are considered to be negligible. Direct sedimentation of algal biomass is supposed to be greater in epipelagic systems exhibiting a high contribution of "new" production sensu Dugdale and Goering in 1967 (LEgendre and LeFEvrr. 1989). There are, however, indications that picoplankton also benefit from nitrate inputs into the euphotic zone (Glover et al., 1988), a significant part of "new" production therefore occurring in the smaller size fraction with negligible sedimentation rates.

About $20-30 \%$ of phytoplankton biomass ingested by mesozooplankton is excreted as fecal pellets (CORKETT and MACLAREN, 1978) that may supplement the vertical flux of biogenic matter. Grazing on phytoplankton also is dependent on its size structure Mesozooplankton is not said to consume picoplankton (JoHNSON et al., 1982: BOAK and GOULDER, 1983). On the other hand, small nano- and microzooplankton, namely heterotrophic flagellates and ciliates, can have a significant grazing pressure on algal biomass (RASSOUlZADEGAN and ETIENNE, 1981; LANDRY and HASSETT, 1982; LANDRY et al. . 1984: BURKILl et al., 1987; GrFFord, 1988), sometimes equal or even higher than that of mesozooplankton (SMetacek, 1981; Capriulo and Carpenter, 1983; Cosper and Stepien. 1984; VERITY, 1985). Although protists can ingest particles about their size or even larger (GOLDMAN and CARON, 1985), picoplankton and small nanoplankton are considered their main food source (FENCHEL, 1987; RassoulzadeGAN et al., 1988). The predominance of microzooplankton grazing will lead to a higher retention of biogenic carbon in surface layers compared to mesozooplankton grazing involving fecal pellet production. "New" production in the picoplankton size class, therefore, will be entrained into the microbial loop and cannot be considered "export" production (PEINERT et al., 1989) over shorter time scales. The size distribution of primary producers, therefore, has a great impact on trophodynamic processes in the euphotic zone as well as productivity/sedimentation conditions (LEGENDRE and LEFÈVRE, 1989).

Data presented here were collected during leg 1 of cruise no. 10 of German R.V. Meteor in March/April 1989 at the two southern NABE (North Atlantic Bloom Experiment) study sites, $18^{\circ} \mathrm{N}, 30^{\circ} \mathrm{W}$ and $33^{\circ} \mathrm{N}, 20^{\circ} \mathrm{W}$. The development of phytoplankton spring blooms and the subsequent sedimentation of biogenic matter at these tropical and subtropical sites are important to "global ocean flux", as two thirds of the world's ocean occur within these latitudes. In this paper we describe the primary productivity regime and phytoplankton size structure in relation to physico-chemical properties of the epipelagic system. Other aspects of this cruise are published elsewhere (Koeve et al., 1993; Lenz et al.. 1993: Passow and Peinert, 1993; Podewski et al., 1993).

\section{MATERIALS AND METHODS}

Since the vertical structure of dynamic processes of the epipelagic system was the main goal of this study, a Lagrangian drogue study was carried out. Samples were taken along the drift track of a drifter rig carrying sediment traps below the euphotic zone $\left(18^{\circ} \mathrm{N} 120 \mathrm{~m}\right.$; $33^{\circ} \mathrm{N} 200 \mathrm{~m}$ ).

The first drift station in the tropical North Atlantic at $18^{\circ} \mathrm{N}, 30^{\circ} \mathrm{W}$ lasted from $27 \mathrm{March}$ to 6 April; 11 days of investigation. The study site was situated within the North Equatorial Current northwest of the Cap Verde islands. The predominant wind-driven Ekman 
transport in this area during the season of study is northwest (STRAMmA and ISEMER, 1988), and the drifter basically followed surface currents (PoDEwski et al., 1993). The second drift station in the subtropical North Atlantic, at $33^{\circ} \mathrm{N}, 21^{\circ} \mathrm{W}$, was studied from 16 April to 24 April ( 9 days). The study site was located within a branch of the southeasterly-flowing Azores current.

Temperature and salinity profiles were taken with a Neil Brown CTD. In situ chlorophyll fluorescence was recorded by a Backscatt fluorescence sensor mounted on a $\mathrm{ME}$ CTD probe (Meereselektronik, Trappenkamp. Germany). Water samples were taken with a 24 bottle multisampler with black 101 Niskin type water bottles.

Dissolved inorganic nutrients were measured according to Grasshoff et al. (1983) with an autoanalyser. Nitrate concentrations determined by the chemoluminescence method (Garside, 1982; Eppley and Koeve, 1990; Koeve et al. . 1993) were provided by R. W. Eppley and W. Koeve; data of morning casts were used. Chlorophyll a (Chl a) was determined either trichomatically (STRICKLAND and PARSONS, 1972) and calculated after JEFFREY and Humphrey (1975) or with a Turner Designs Model 10 fluorometer calibrated against trichomatically determined Chl $a$ after filtration of samples onto $25 \mathrm{~mm}$ Whatman GF/F filters.

The abundance of autotrophic picoplankton and autotrophic flagellates $3-5, \mathrm{~m}$ in size was determined by epifluorescence microscopy on black-stained $0.2 \mu \mathrm{m}$ Nuclepore filters under blue light excitation $(450-490 \mathrm{~nm})$. Samples were filtered without fixation and cell numbers were estimated directly afterwards or from deep-frozen filters after the cruise. For picocyanobacteria, more than 200 cells were counted (mean error $<10 \%$ ), for eucaryotic picoplankton at least 50 cells (mean error $<32 \%$; VENRICK, 1978).

Primary production was measured by in situ ${ }^{14} \mathrm{CO}_{2}$ incubations (Steemann Nielsen. 1952 ) of $12 \mathrm{~h}$ duration (dawn to dusk) in $250 \mathrm{ml}$ polycarbonate bottles ( $25, \mathrm{Ci}$ per bottle). Two bottles treated with $1 \times 10^{-5}$ mol $1^{-1}$ DCMU [3-(3.4-dichlorphenyl)-1. 1-dimethylurea; LEGENDRE et al. . 1983] were used as dark correction and subtracted from light bottles. After incubation, samples were treated with $1.5 \times 10^{-5} \mathrm{~mol} \mathrm{DCMU}^{-1}$ to prevent carbon uptake while bottles were processed. Bottle contents subsequently were fractionated and filtered onto Whatman GF/F filters. Earlier experiments revealed no significant differences between $0.45 \mu \mathrm{m}$ membrane filters and GF/F filters in primary productivity measurements (Li et al., 1983; HerbLand et al., 1985; JoCHEM, 1987), and Li (1986) reported $98.1-99.4 \%$ retention of Synechococcus on GF/F filters. ${ }^{1+} \mathrm{C}$-uptake was determined by liquid scintillation measurements in a Packard TriCarb.

For size fractionation "total", " $<20 \mu \mathrm{m}$ " and " $<2 \mu \mathrm{m}$ ", post-screening classes were used. Aliquots $(75 \mathrm{ml})$ were used for fractionation to avoid variance due to the use of different bottles. Estimates for "total" were obtained from untreated aliquots, the other two aliquots were filtered through $20 \mu \mathrm{m}$ net gauze and $25 \mathrm{~mm} 2.0 \mu \mathrm{m}$ Nuclepore filters (pressure $<300 \mathrm{mbar}$ ), respectively. The filtrates were again filtered onto $\mathrm{GF} / \mathrm{F}$ filters. The same size fractionation procedure was used for chlorophyll but 21 were fractionated and two $2.0 \mu \mathrm{m}$ Nuclepore filters of $47 \mathrm{~mm}$ diameter were used for each sample.

\section{RESULTS}

\section{The tropical North Atlantic at $18^{\circ} \mathrm{N}$}

Profiles of density ( $\sigma_{\theta} ;$ Fig. 1a) indicate that the main pycnocline at about $50-60 \mathrm{~m}$ depth became more pronounced during the course of the time series. This pycnocline can be 


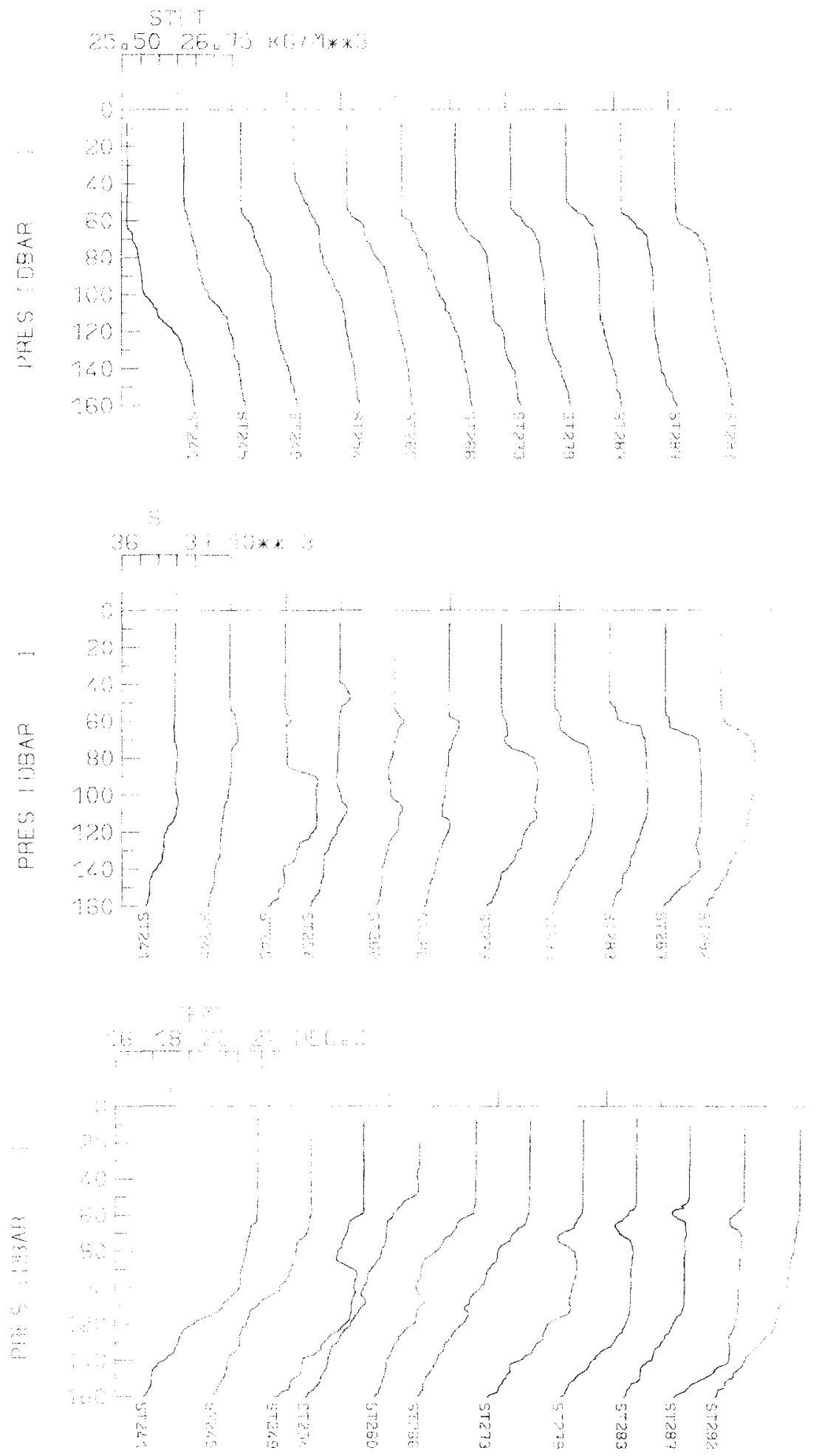


considered the result of winter mixing, the overlying water therefore representing the winter mixed layer (WML). Temperature was about $21.8^{\circ} \mathrm{C}$ and salinity about $36.7 \%$, almost homogeneous throughout this water layer (Fig. 1b,c). Diurnal vertical mixing was restricted, however, to less than $20 \mathrm{~m}$. Based on several more CTD profiles and objective data analysis, PoDewski et al. (1993) concluded that the drifter stayed approximately within the same water body until day 6 (Sta. 266, 1 April) but then crossed a frontal structure.

An obvious feature was the encounter of high salinity water, termed Subtropical Salinity Maximum Water ( $S_{\max }$; PoDewski et al., 1993), below the main pycnocline. Once during the first half of the study (Sta. 249) and more commonly during the second half (Stas 273$287)$ a small layer of low salinity low temperature water $\left(S_{\min }\right)$ could be detected within the upper part of $S_{\max }$. From detailed analysis of hydrographic data it became clear that, due to its density, $S_{\max }$ water split and intruded into the pycnocline water mass, yielding an upper and a deeper part of $S_{\max } ; S_{\min }$ represented original pycnocline water that remained at the respective depth due to interleavings of $S_{\max }$ and pycnocline water. This vertical zonation of water masses is best seen in temperature profiles (Fig. 1c). On the last day (Sta. 292), no $S_{\min }$ layer could be detected in the morning profiles and pure $S_{\max }$ water was found below the main pycnocline down to about $120 \mathrm{~m}$. A detailed description of this feature is given elsewhere in this volume (Koeve et al., 1993; Ponewski et al., 1993).

Except on the first day, global irradiation was fairly constant throughout the study period, mean irradiation (mean for dawn to dusk) being about $400-500 \mathrm{~W} \mathrm{~m}^{-2} \mathrm{~h}^{-1}$. The daily course of irradiation was symmetric with a maximum at local noon, indicating that incubation time for primary production $(07.00$ to $19.00 \mathrm{~h})$ covered the daylight period (JoCHEM, 1990).

The WML was depleted of nutrients (Fig. 2a-d), concentrations of silicate and phosphate being less than $0.2 \mu \mathrm{mol}^{-1}$, and nitrate concentrations in the nanomolar range (EPPley and Koeve, 1990; Koeve et al., 1993). The nutricline was found at about $70 \mathrm{~m}$ depth the first two days but at about $50-60 \mathrm{~m}$ depth thereafter, thus related to the main pycnocline. Nitrite showed its primary maximum of up to $0.15 \mu \mathrm{mol} \mathrm{l}^{-1}$ at about $80 \mathrm{~m}$ depth. The occurrence of $S_{\max }$ water deepened the main nutricline as well as the primary nitrite maximum to more than $100 \mathrm{~m}$ depth, below the euphotic zone. The $S_{\min }$ water at about $50-80 \mathrm{~m}$ depth partitioned the $S_{\max }$ water into an upper and a deeper part displaying much higher nitrate concentrations $\left(>0.5 \mu \mathrm{mol} \mathrm{l}^{-1}\right)$. The vertical extent, as well as the nitrate content of this water mass, decreased over the course of this study (KoEve et al, , 1993). On the last day (Sta. 292), the nitrate-rich $S_{\min }$ was not found in the morning casts and the nutricline occurred, although less pronounced, at about $90 \mathrm{~m}$ depth.

Vertical profiles of in situ fluorescence as a relative measure of chlorophyll (Fig. 3) generally showed the presence of a subsurface chlorophyll maximum at varying depths. On the last day (Sta. 292), no distinct fluorescence maximum could be detected. Chlorophyll concentrations derived from water samples generally gave the same picture (Fig. 4), although the maximum layer did not always coincide with depths obtained from in situ fluorescence profiles. Within the subsurface maximum, chlorophyll concentrations were always higher than $0.37 \mu \mathrm{g}^{-1}$, reaching as high as $0.99 \mu \mathrm{g} \mathrm{l} \mathrm{I}^{-1}$. The depth horizon of

Fig. 1. Profiles of density $\left(\sigma_{\theta}\right)$. salinity and temperature taken at dawn each day at the $18^{\circ} \mathrm{N}$ study site. 
(a) Day No.

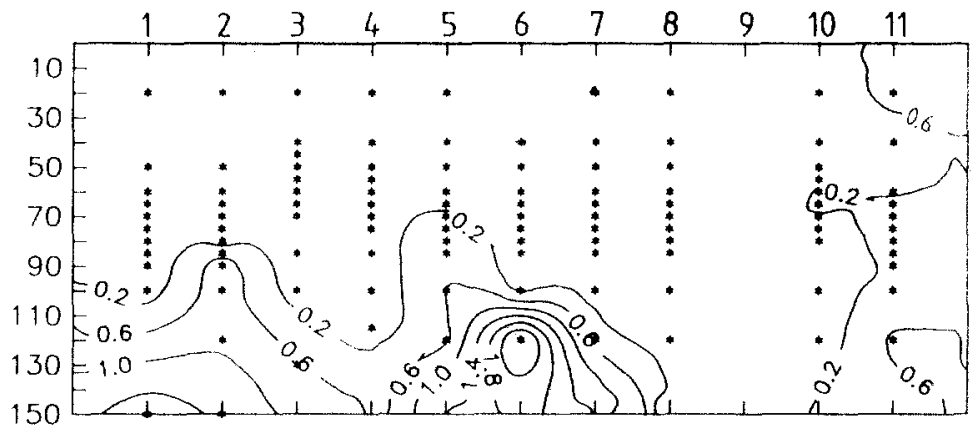

(b)

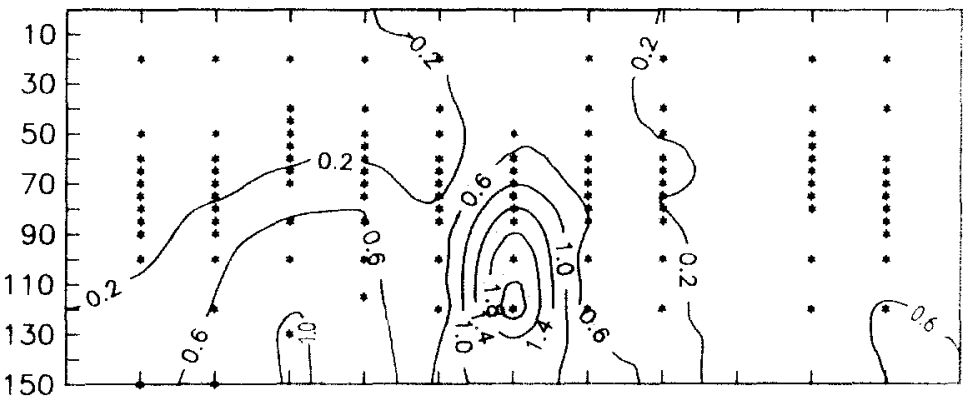

(c)

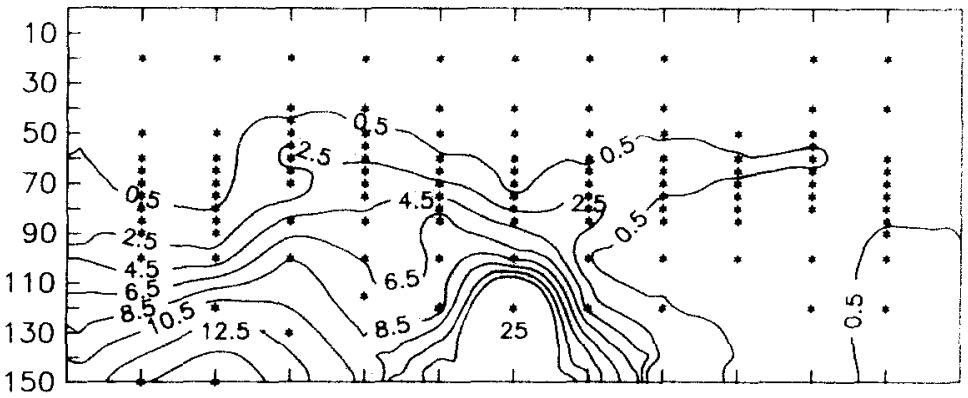

(d)

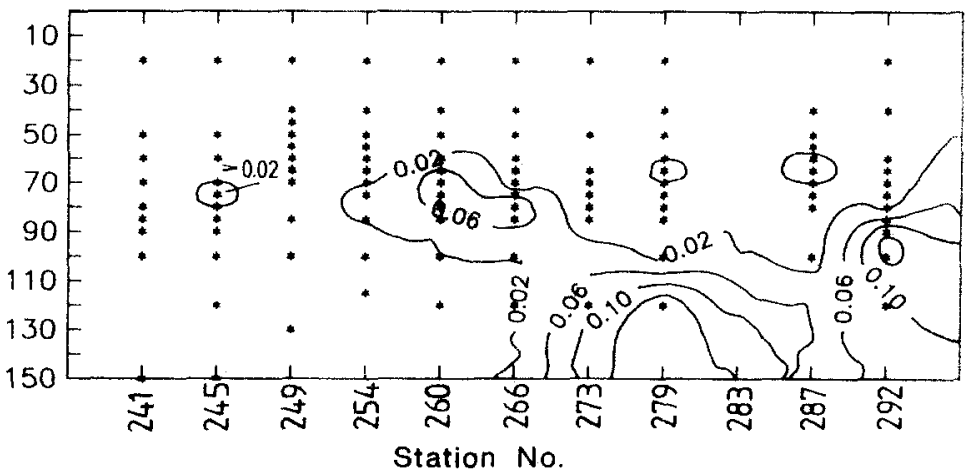

Fig. 2. Nutrient concentrations $\left(\mu \mathrm{mol} \mathrm{I}^{-1}\right)$ trom morning casts at the $18^{\circ} \mathrm{N}$ study site; (a) silicate (b) phosphate, (c) nitrate, (d) nitrite. 


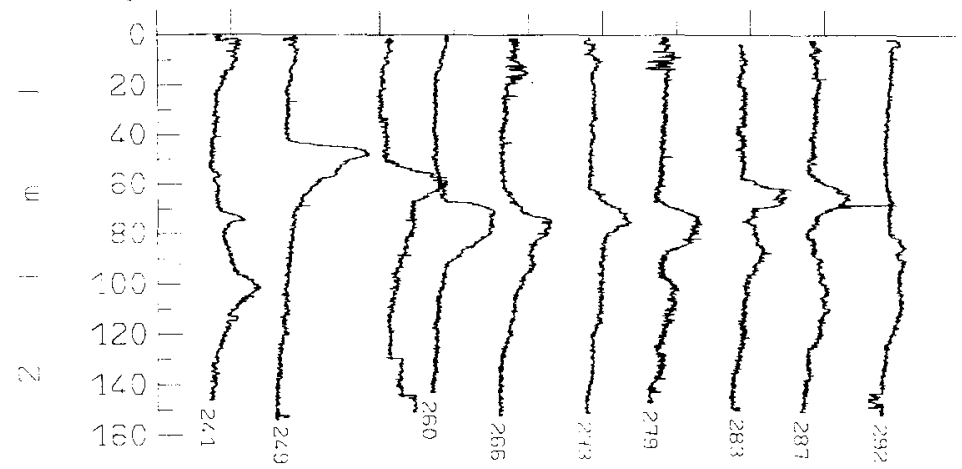

Fig. 3. In situ fluorescence (relative units) taken at dawn each day at the $18^{\circ} \mathrm{N}$ study site.

the subsurface chlorophyll maximum was situated just above the nutricline and pycnocline. This was also the depth horizon of nitrate-rich $S_{\min }$ water so that chlorophyll maxima occurred within $S_{\min }$ when encountered. Integrated chlorophyll (upper $100 \mathrm{~m}$ ) showed no significant trends (19-51 $\mathrm{mg} \mathrm{m}^{-2}$, mean $34 \mathrm{mg} \mathrm{m}^{-2}$ ), and about two thirds of phytoplankton biomass were found in the subsurface maximum (Fig. 5). Stations 273 and 283 were marked by somewhat higher concentrations and a lower contribution of the subsurface maximum.

Size fractionation of chlorophyll (Fig. 5) revealed picoplankton as the dominant size fraction, accounting for 78-90\%. An obvious exception was Sta. 273 (day 7) where only $<55 \%$ of chlorophyll was contributed by the $<2 \mu$ m class. It was only at this station that microplankton chlorophyll, generally less than $0.04 \mu \mathrm{g} \mathrm{l}^{-1}$ and often not detected, reached a contribution of $87.5 \%\left(0.35 \mu \mathrm{g}{ }^{-1}\right)$ at $60-80 \mathrm{~m}$ depth. Nanoplankton also showed higher concentrations (up to $0.25 \mu \mathrm{g} \mathrm{l}^{-1}$ ) and contribution (54\%) at this station, but at $40 \mathrm{~m}$ depth and thus above the microplankton population. Based on integrated chlorophyll, microplankton contributed $25 \%$ and nanoplankton $23 \%$ at Sta. 273.

Picocyanobacteria, eucaryotic picoplankton and autotrophic flagellates $3-5 \mu \mathrm{m}$ all

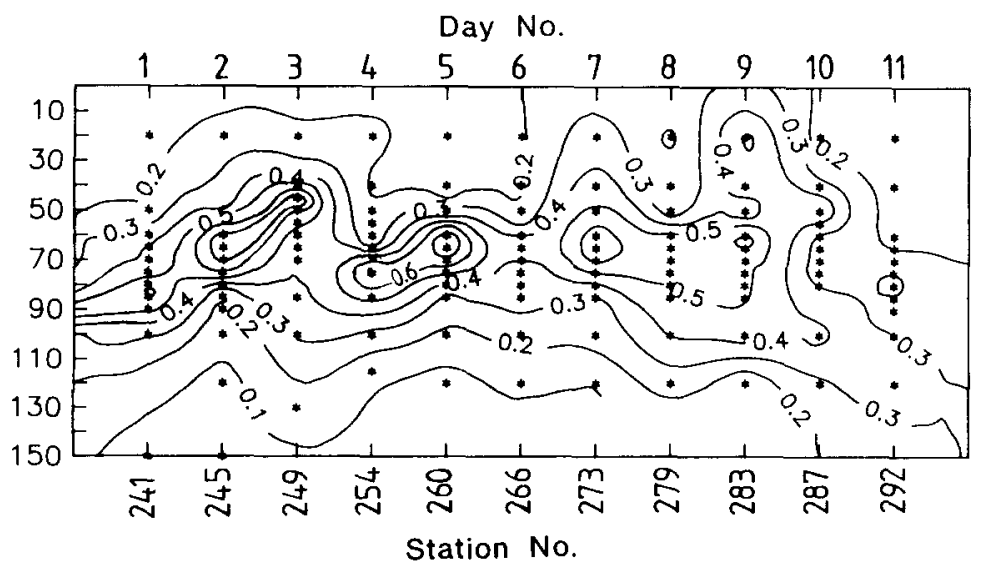

Fig. 4. Chlorophyll concentrations $\left(\mu \mathrm{g} \mathrm{l}^{-1}\right)$ from morning casts at the $18^{\circ} \mathrm{N}$ study site. 


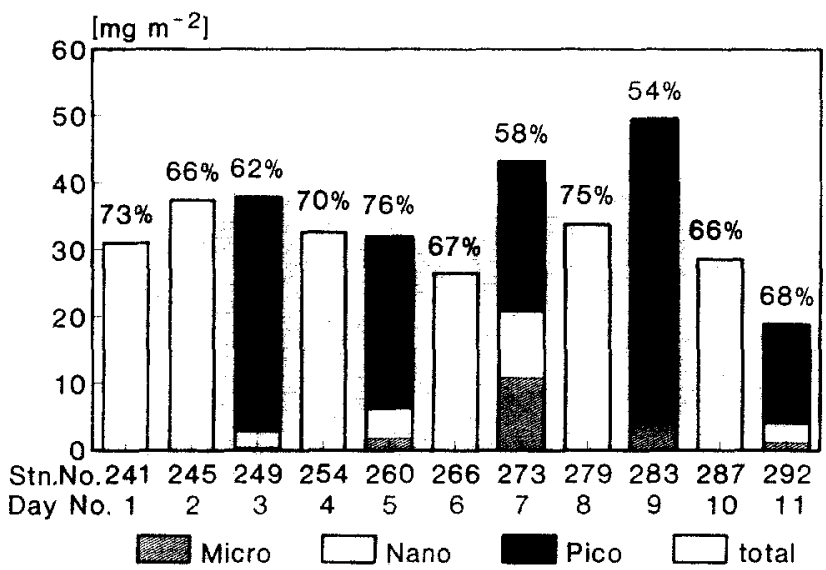

Fig. 5. Size-factionated integrated chlorophyll $\left(\mathrm{mg} \mathrm{m}^{2}\right.$, from morning casts, $100 \mathrm{~m}$ witu: column. at the $18^{\circ} \mathrm{N}$ study site. Numbers on top of each har indicate the contribution of the subsurface maximum to total water column chlorophyll.

showed population maxima within the subsurface chlorophyll maximum (Fig. 6). Cell numbers of picocyanobacteria in the upper $80 \mathrm{~m}$ were $>10^{7} \mathrm{I}^{-1}$, those of flagellates $>10^{6} \mathrm{I}^{-1}$. Highest abundances (up to $6.3 \times 10^{7}$ picocyanobacteria $\mathrm{I}^{-1}$ and $1.1 \times 10^{7}$ picoeucaryotes $1^{-1}$ ) were encountered at Sta. 260. While picoeucaryotes and flagellates 3-5 $\mu \mathrm{m}$ always had their population maxima at the same depths, picocyanobacteria maxima occurred 5-10 m shallower at Stas 249 and 266 but at the same depth as picoeucaryotes at Stas 260 and 279. Population maxima of picocyanobacteria occurred in the upper half of the chlorophyll maximum. They were much more abundant than picoeucaryotes, abundance ratios (ratio of cell numbers of cyanobacteria to eucaryotes: Fig. 7) being 10-36 in the WML water. Abundance ratios generally decreased with depth and approached 1-2 below the subsurface maximum. The two stations influenced by the $S_{\text {max }} / S_{\text {min }}$ intrusion (Stas 249,279) showed a distinct deviation from the general pattern related to this hydrographic feature. At about $70-80 \mathrm{~m}$ depth, i.e. within the $S_{\text {mix }}$ water. abundance ratios were higher again.

During the first six days of the drift station. primary productivity showed subsurface maxima ( $>0.5 \mu \mathrm{g} \mathrm{C}^{-1} \mathrm{~h}^{-1}$ ) which corresponded to chlorophyll subsurface maxima (Fig 8). The highest productivity during this phase was encountered at Sta. 260. Unfortunately there are only two measurements at stations exhibiting $S_{\max } / S_{\min }$ intrusions (Stas 249 . 279). While no effects of water mass intrusions were discernible at Sta. 249 , productivity at Sta. 279 was significantly higher and exhibited a pronounced surface maximum. Similar results can be drawn from integrated productivity (upper $100 \mathrm{~m}$; Fig. 9). During the first six days, productivity amounted to about $0.44 \mathrm{~g} \mathrm{C} \mathrm{m}^{2} \mathrm{day}^{-1}$ but as much as $1.1 \mathrm{~g} \mathrm{C} \mathrm{m}{ }^{2}$ day were measured at Sta. 279. On the last day (Sta. 292). integrated primary productivity was about the same as found before Sta. 279, although no distinct subsurface productivity maximum did occur. At Stas 254-266, which were less influenced by intrusion of $S_{\max }$ water into pycnocline water, about two thirds of water column production were derived from the subsurface maximum layer. At stations influenced by $S_{\max } / S_{\min }$ intrusions (Stas $249,279)$, the contribution of WML to water column productivity was about twice as high. 


\section{Cyanobacteria}

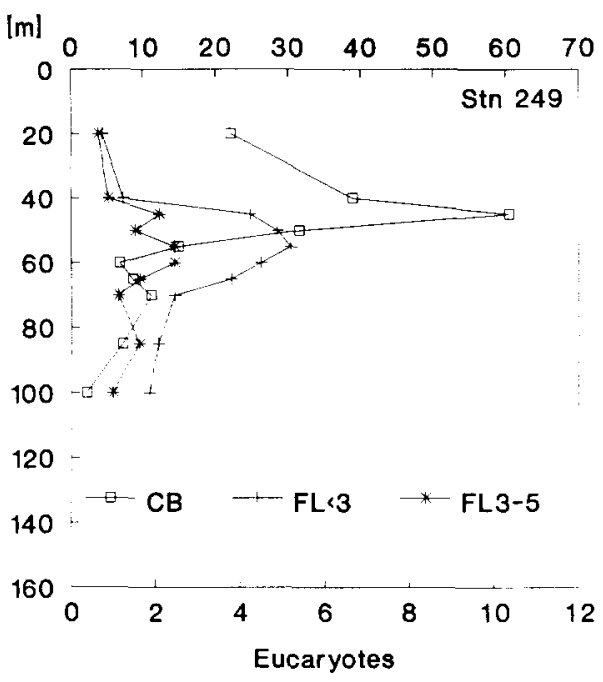

Cyanobacteria

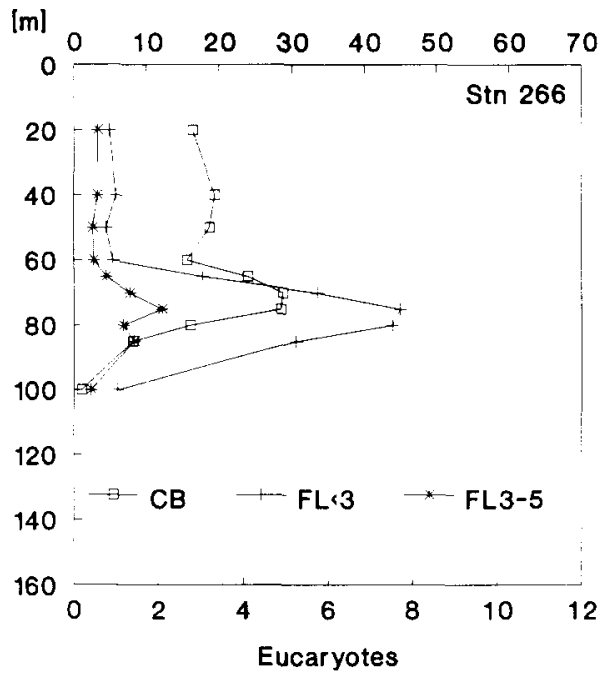

Cyanobacteria

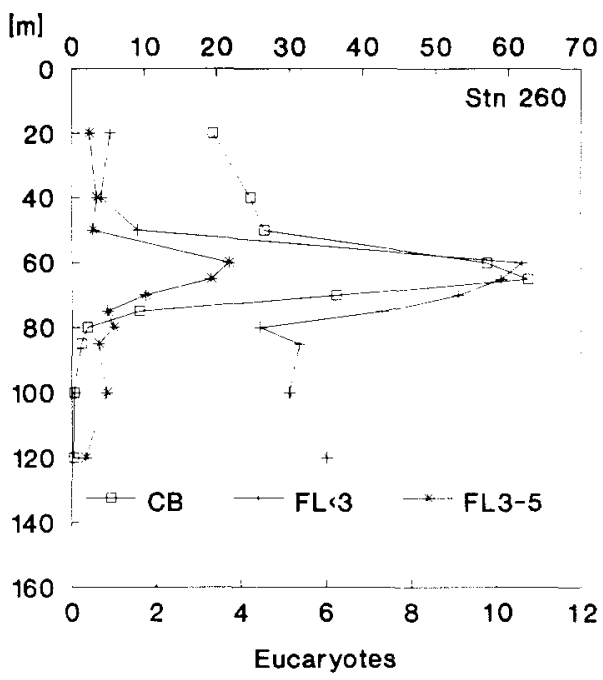

Cyanobacteria

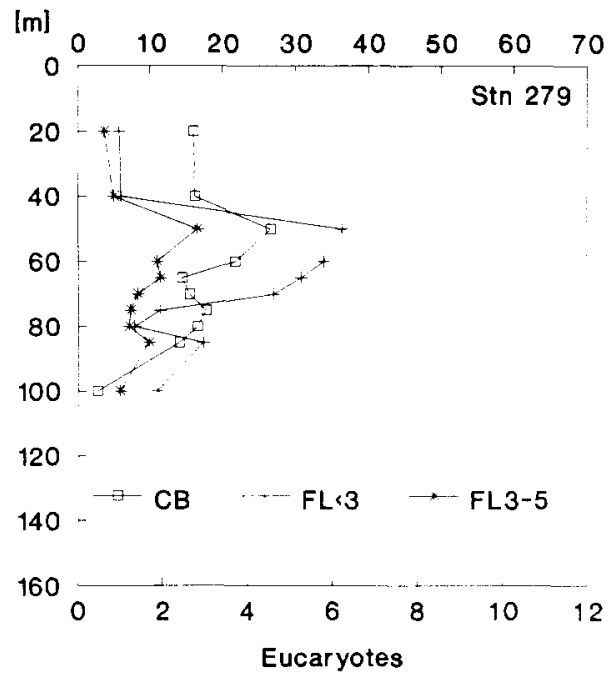

Fig. 6. Profiles of phototrophic picoplankton (picocyanobacteria $=\mathrm{CB}$; eucaryotes $=\mathrm{FL}<3$ ) and small phototrophic nanoflagellates $3-5 \mu \mathrm{m}$ in size (FL3-5) abundance $\left(10^{6}\right.$ cells $\left.\mathrm{I}^{-1}\right)$ at the $18^{\circ} \mathrm{N}$ study site.

Size fractionation of primary production again revealed picoplankton to be the dominant size class, contribution greater than $80 \%$; occasionally, no carbon uptake could be detected in the micro- and nanoplankton. Only at Sta. 279 did microplankton show higher production near the surface, reaching a contribution of $2.6 \%$ of integrated productivity. Picoplankton also showed its highest productivity at the upper edge of $S_{\min }$ water at Sta. 279. 


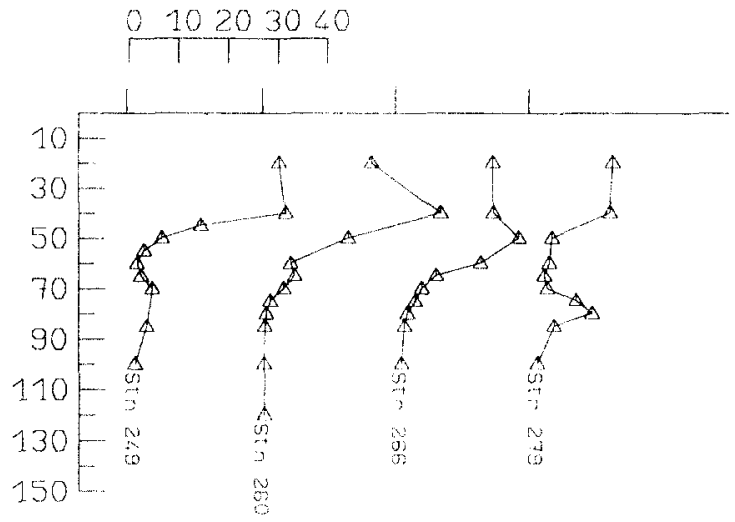

Fig. 7. Abundance ratios (ratio of cell numbers of picocyanobacteriat to picoeucaryotes) at the $18^{\circ} \mathrm{N}$ study site.

\section{The subtropical North Atlantic at $33^{\circ} \mathrm{N}$}

Compared to the situation at $18^{\circ} \mathrm{N}$, hydrographic vertical gradients and temporil changes were much less pronounced at the $33^{\circ} \mathrm{N}$ study site. Typical profiles of density $\left(\sigma_{\theta}\right)$. salinity and temperature (Sta. 376, day 4 and Sta. 387, day 6; Fig. 10) show that actual mixing was very shallow, never exceeding $20 \mathrm{~m}$. and the density gradient was very low $\left(<0.002 \mathrm{~m}^{-1}\right.$ compared to $0.025 \mathrm{~m}^{-1}$ in the pycnocline at $\left.18^{\circ} \mathrm{N}\right)$. Temperature was about $17.6^{\circ} \mathrm{C}$ and salinity about $36.5 \%$; neither varied much down to the main pycnocline at $160 \mathrm{~m}$. This can be considered the depth of winter mixing.

Despite the more northerly position of the study site, the light regime in terms of irradiation and daylength was the same as at $18^{\circ} \mathrm{N}$ (JOCHEM, 1990).

Most of the euphotic zone was nutrient-depleted, nitrate concentrations having been $<0.1 \mu \mathrm{moll}^{-1}$ down to $40-60 \mathrm{~m}$ (Fig. 11). At Sta. 366, the nutricline was found below $80 \mathrm{~m}$. and Sta. 376 (day 4) showed an intrusion of nitrate-rich water between 30 and $75 \mathrm{~m}$. probably related to lower temperatures $\left(<17^{\circ} \mathrm{C}\right)$ and lower salinity (Fig. $\left.10 \mathrm{a}\right)$. At the end of the study period, nitrate concentrations below $70 \mathrm{~m}$ increased. Measurements of other

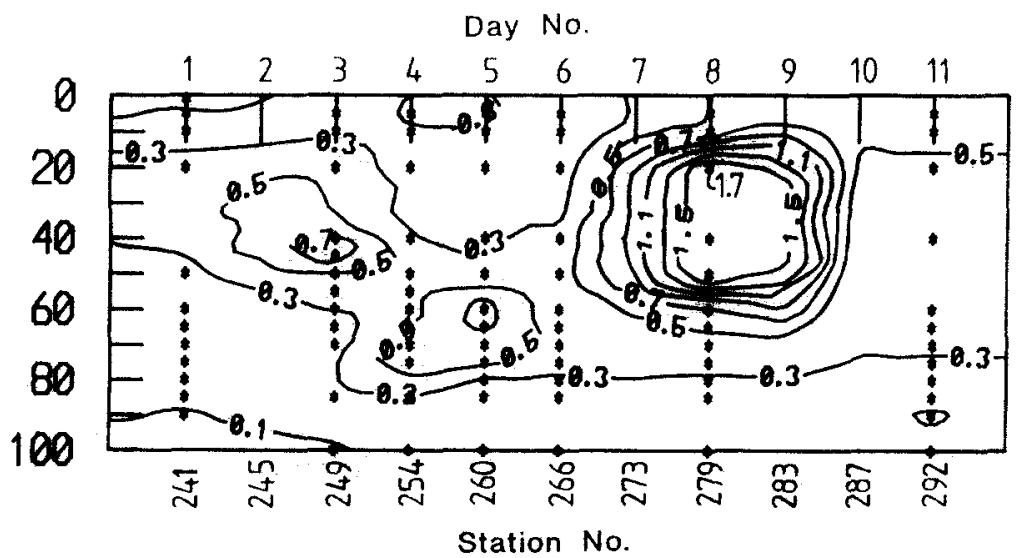

Fig. 8. Primary production ( $\left.\mu \mathrm{g} \mathrm{C} !^{-1} \mathrm{~h}^{-1}\right)$ at the $18^{\circ} \mathrm{N}$ study site from $12 \mathrm{~h}$ in simu incubations. 


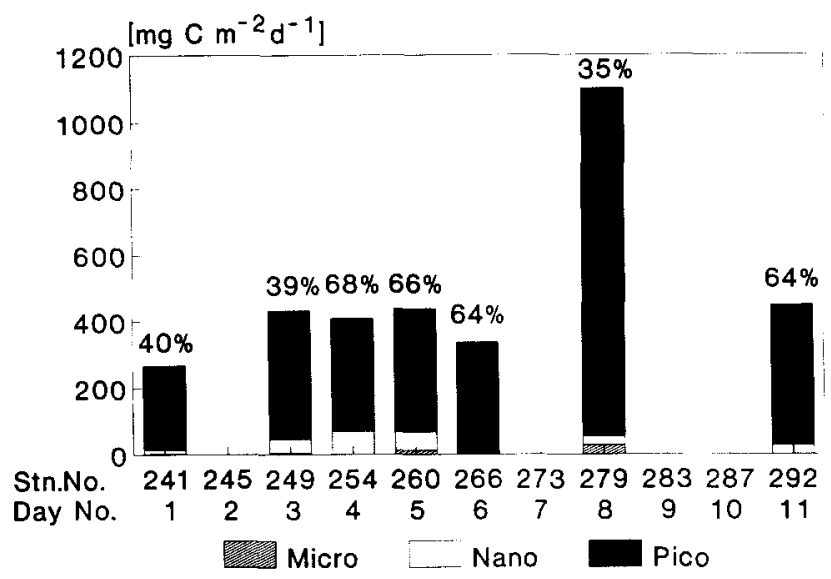

Fig. 9. Size-fractionated integrated primary production $\left(\mathrm{mg} \mathrm{C} \mathrm{m}^{-2} \mathrm{day}^{-1}\right), 100 \mathrm{~m}$ water column. at the $18^{\circ} \mathrm{N}$ study site. Numbers on top of each bar indicate the contribution of the subsurface maximum to total water column chlorophyll.

inorganic nutrients were available for only two stations (Stas 361, 376; data not depicted here). The nitrite maximum (up to $0.38 \mu \mathrm{mol} \mathrm{I}^{-1}$ ) occurred at $80-150 \mathrm{~m}$ depth while phosphate showed a clear nutricline at $80 \mathrm{~m}$ depth above which concentrations were well below $0.1 \mu \mathrm{mol} \mathrm{I}^{-1}$.

Vertical profiles of in situ fluorescence (Fig. 12) showed a much higher variability and were fairly spiky compared to those in Fig. 3, the latter indicating the occurrence of larger phytoplankton. During the first four days, variability was high and weak subsurface maxima or surface maxima were recorded. It was not until day 5 (Sta. 382) that a distinct subsurface maximum was seen at about 40-65 m depth. Station 376 showed two small subsurface maxima, which probably were the result of the intrusion of the nitrate-rich low temperature water mass with a low phototrophic biomass (see above). No fluorescence profiles were available from Stas 398 and 403, the last two days of the drift station.

Chlorophyll measurements derived from discrete water samples (Fig. 13) showed the same variability and generally followed the trends seen in in situ fluorescence profiles. From these measurements it can be seen that Sta. 398 also exhibited a distinct subsurface maximum, but not Sta. 403. Concentrations within the subsurface maximum were $>0.6 \mu \mathrm{g}$ $\mathrm{I}^{-1}$, up to $1 \mu \mathrm{g} \mathrm{l}^{-1}$. Chlorophyll values within the subsurface maximum were only slightly higher compared to those at the $18^{\circ} \mathrm{N}$ drift station, but concentrations above and below the subsurface maximum were significantly higher at $33^{\circ} \mathrm{N}$. Therefore, integrated chlorophyll (upper $100 \mathrm{~m} ; 20-73 \mathrm{mg} \mathrm{m}^{-2}$; Fig. 14) was higher compared to $18^{\circ} \mathrm{N}$. decreasing over the 9-day sampling period.

Picoplankton was the dominant size class in chlorophyll size fractionation (generally $>42 \%$ of total chlorophyll), although its contribution was lower compared to $18^{\circ} \mathrm{N}$. Microplankton chlorophyll concentrations usually were less than $0.2 \mathrm{ug} \mathrm{l}^{-1}$; an exception was Sta. 382 (day 5) when microplankton reached up to $0.96 \mu \mathrm{gl}^{-1}$, contributing $\leq 86 \%$ of the subsurface chlorophyll maximum. Similarly, at Sta. 398 (day 8) microplankton reached values up to $0.42 \mu \mathrm{g} \mathrm{I}^{-1}$ at $60 \mathrm{~m}$ depth and contributed $41 \%$ to total chlorophyll. Concentrations of nanoplankton chlorophyll were in the same range as for microplankton. At Stas 382 (day 5) and 387 (day 6). nanoplankton showed higher chlorophyll biomass 


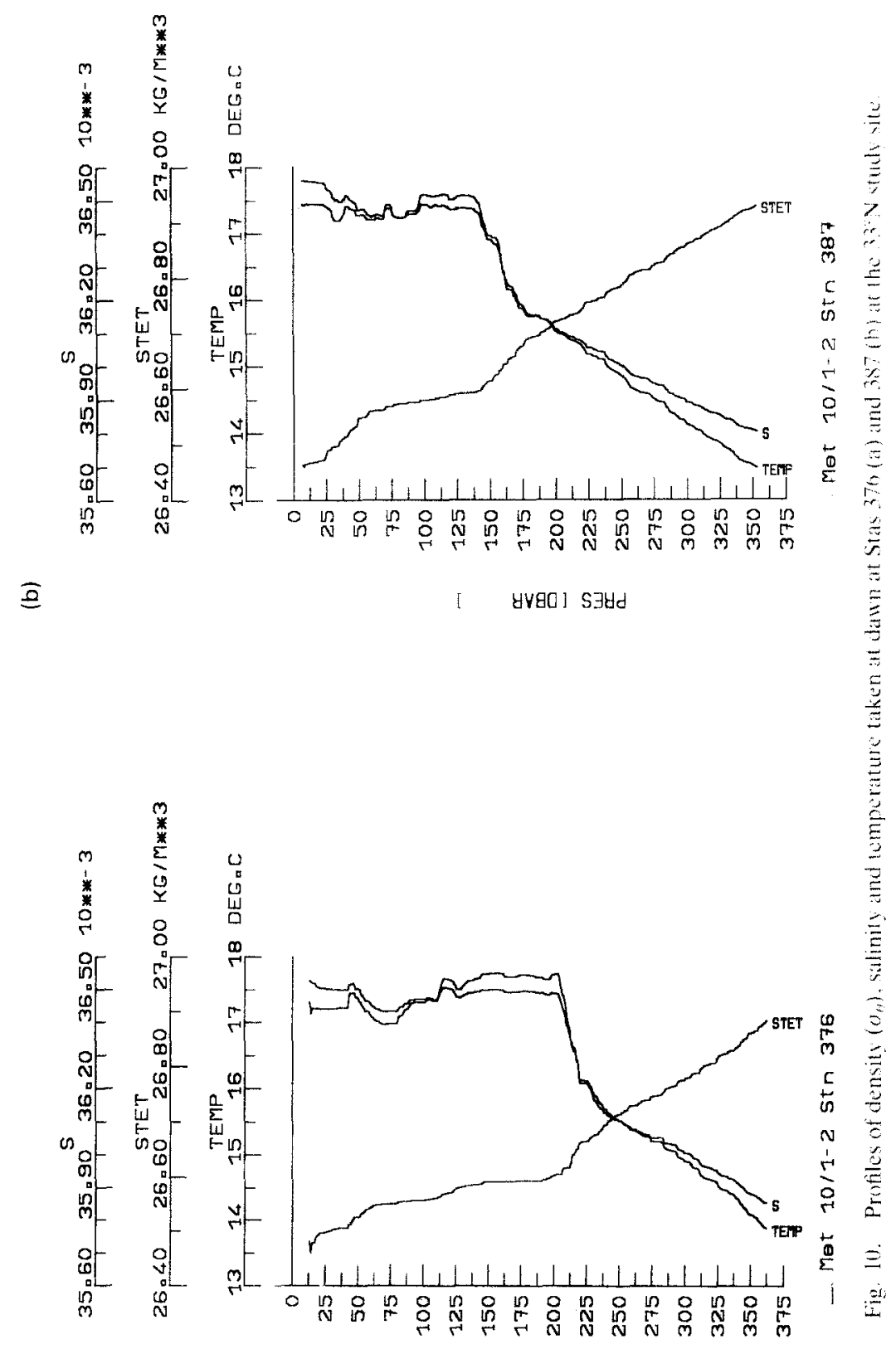




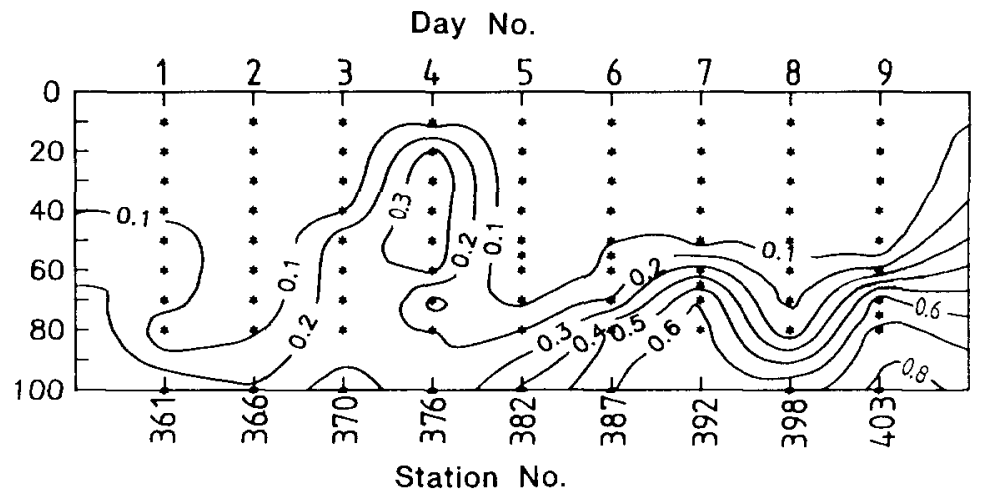

Fig. 11. Nitrate concentrations $\left(u \mathrm{~mol}^{-1}\right)$ from morning casts at the $33^{\circ} \mathrm{N}$ study site.

$\left(\leq 0.67 \mu \mathrm{g} \mathrm{l}^{-1}\right)$ in the upper $30 \mathrm{~m}$. Both high concentrations of micro- and nanoplankton at Sta. 382 resulted in an exceptionally low contribution of picoplankton to total integrated chlorophyll (Fig. 14).

Picocyanobacteria, autotrophic picoflagellates and autotrophic flagellates $3-5 \mu \mathrm{m}$ showed similar vertical profiles of their abundances (Fig. 15a-c). All exhibited a subsurface maximum, except picocyanobacteria on the first day. Cell numbers of picocyanobacteria in the upper $80 \mathrm{~m}$ were $>1.5 \times 10^{7} \mathrm{I}^{-1}$, the highest abundance being recorded at Sta. 366 (day $2 ; \leq 7 \times 10^{7} 1^{-1}$ ), coincident with the highest cell numbers of eucaryotic picoplankton $\left(7 \times 10^{6} 1^{-1}\right)$ and phytoflagellates $3-5 \mu \mathrm{m}$.

During the first two days, the population maxima of picocyanobacteria and picoeucaryotes were found at 30 and $60 \mathrm{~m}$ depth, respectively. Concordant with the deepening of both the nutricline and the chlorophyll maximum on day 2 (Sta. 366), population maxima of autotrophic picoplankton were also deeper. The population maximum of picocyanobacteria shifted towards shallower depths during the course of the second half of the study period so that it was found above that of eucaryotes, the latter having had their highest abundances just above the nutricline. Phytoflagellates $3-5 \mu \mathrm{m}$ had their population maxima at the same depth as picoeucaryotes.

Picocyanobacteria dominated phototrophic picoplankton and abundance ratios of

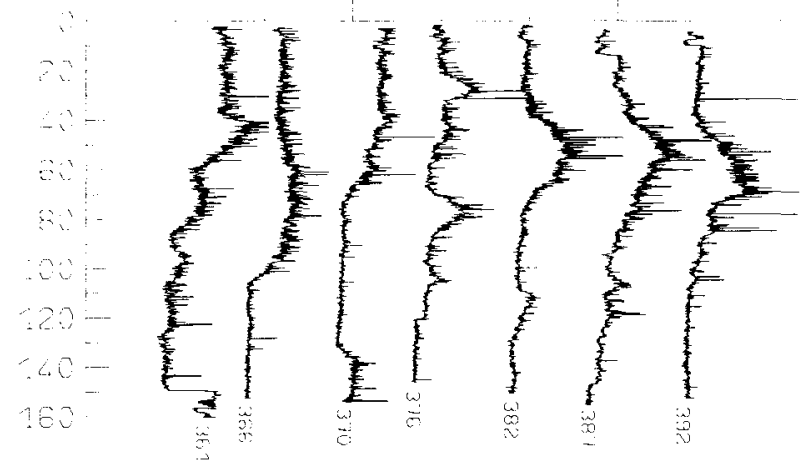

Fig. 12. In situ fluorescence (relative units) taken at dawn each day at the $33^{\circ} \mathrm{N}$ study site. 


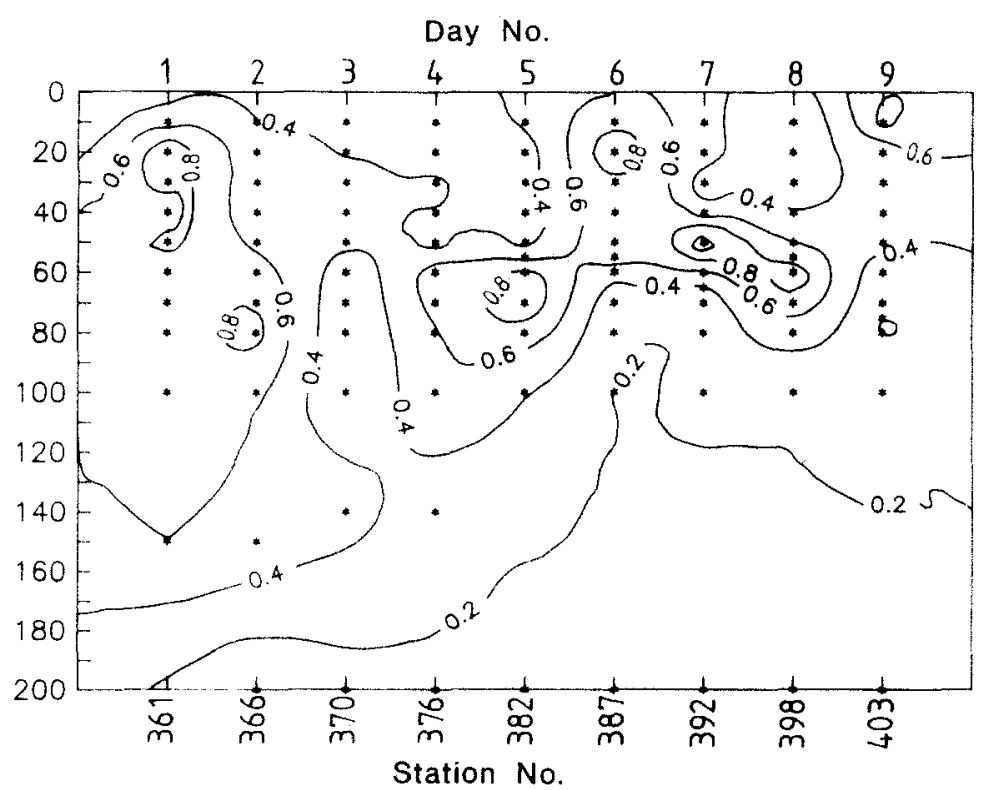

Fig. 13. Chlorophyll concentrations $\left(\mu \mathrm{g} \mathrm{I}^{\prime}\right.$ ') from morning casts at the $33^{\circ} \mathrm{N}$ study site

picocyanobacteria to picoeucaryotes were as high as 71 (Fig. 16). They generally decreased with depth, as already shown for $18^{\circ} \mathrm{N}$. Very near the surface, ratios were lower at four out of six stations; autofluorescence of picocyanobacteria was very weak near the surface, and lower abundance ratios may indicate an underestimation of picocyanobac-

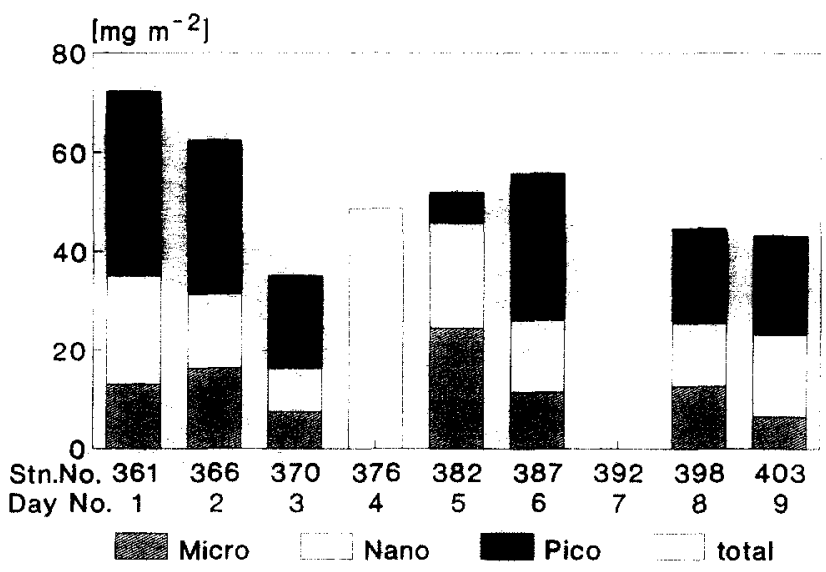

Fig. 14. Size-fractionated integrated chlorophyll ( $\mathrm{mg} \mathrm{m}^{22}$ ) from morning casts. 100 in water column, at the $33^{\circ} \mathrm{N}$ study site.

Fig. 15. Abundance $\left(10^{6}\right.$ cells $\left.1^{1}\right)$ of picocyanobacteria (a), phototrophic picoeucaryotes (b) and phototrophic nanoflagellates $3-5 \mu \mathrm{m}$ in size (c) at the $33^{\circ} \mathrm{N}$ study site. 
Day No.

(a)

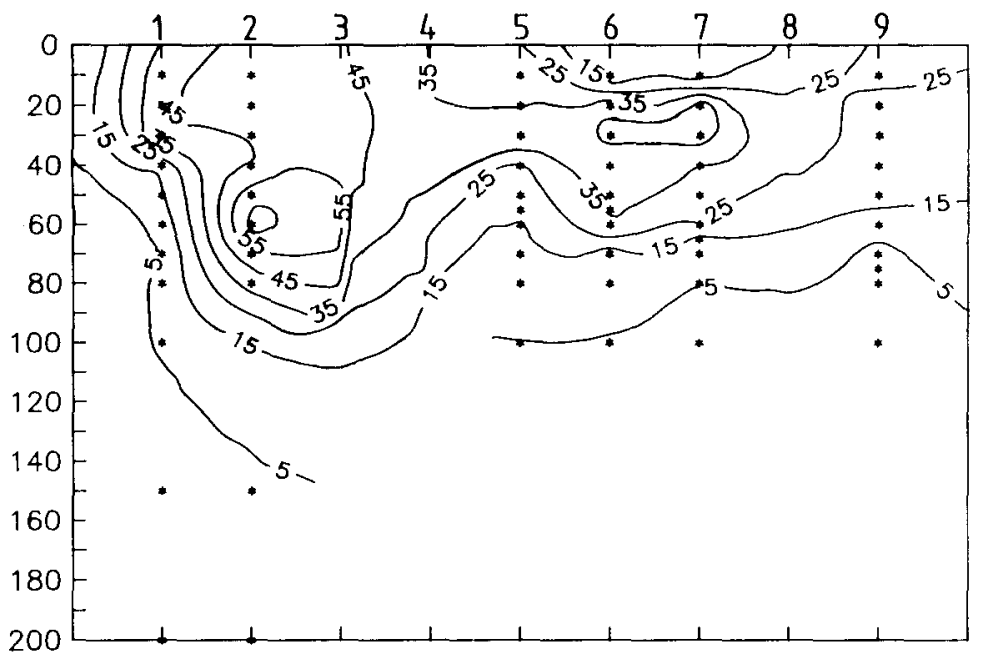

(b)

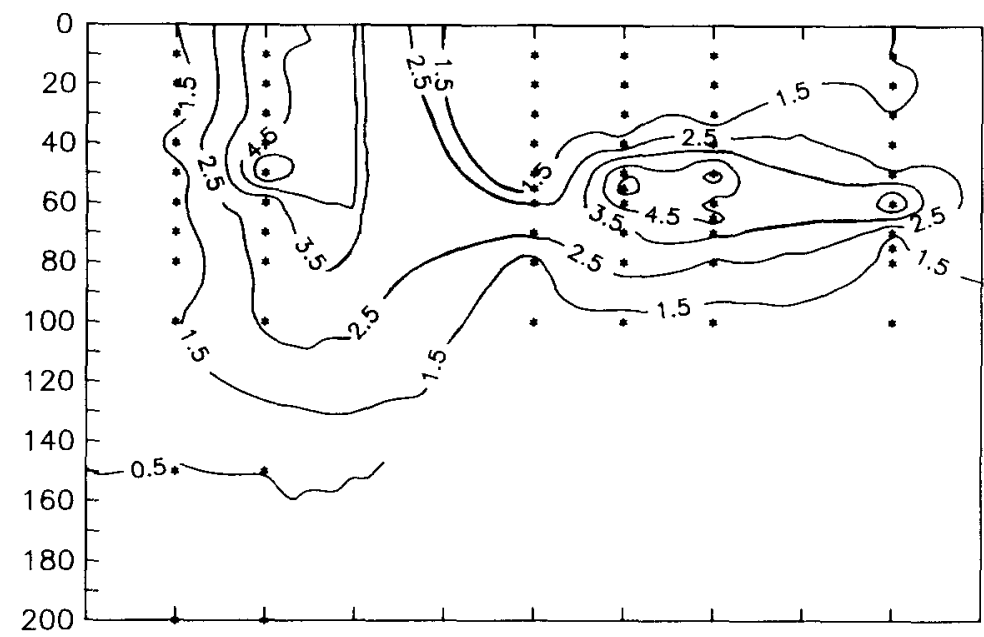

(c)

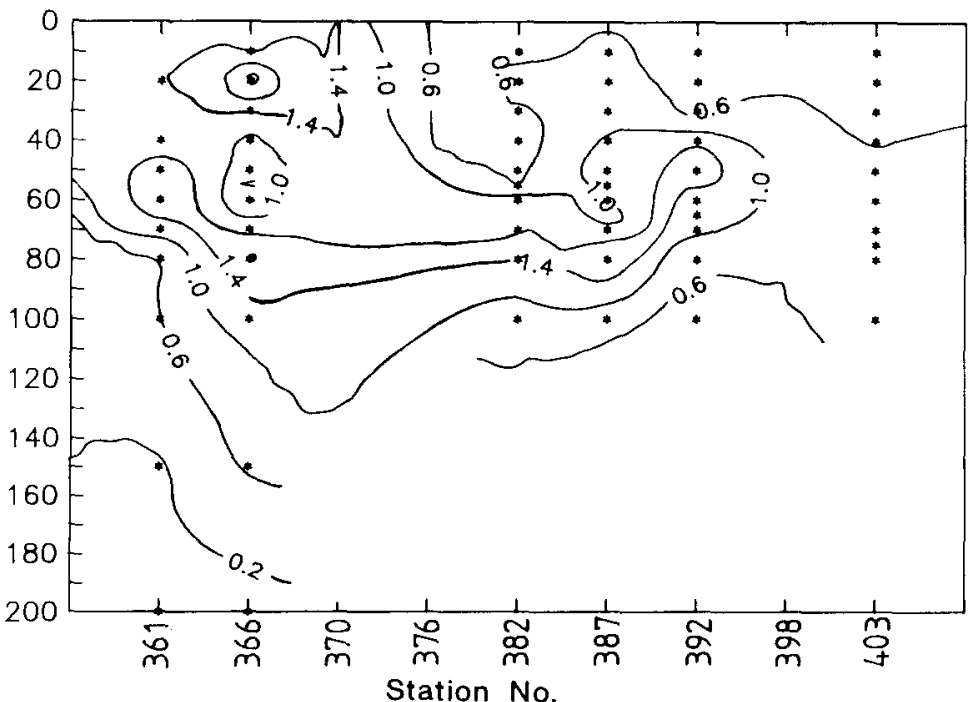




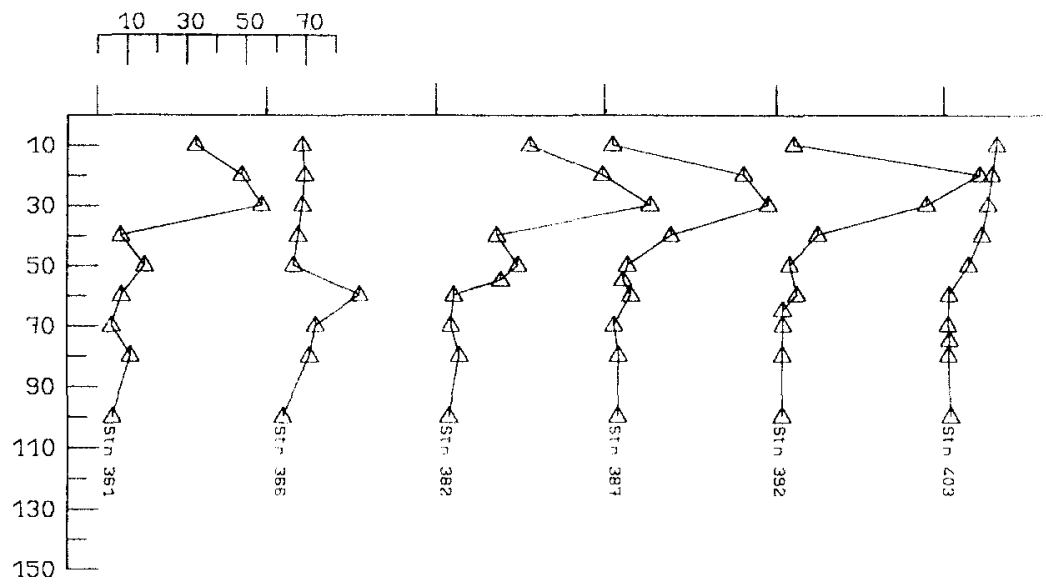

Fig. 16. Abundance ratios (ratio of cell numbers of picocyanobacteria to picueucaryotes) at the $3.3^{\circ} \mathrm{N}$ study site.

teria cell numbers in those samples. Even detection by flow cytometry (Coulter EPICS V) sometimes was difficult in these samples due to low autofluorescence (P. Burkill, personal communication). Cell numbers of picocyanobacteria determined by flow cytometry and epifluorescence microscopy generally agreed except near the surface where flow cytometry gave lower cell numbers compared to microscopy (BurkILL and Jochem, unpublished data). Stations 366 and 403 generally exhibited lower abundance ratios mote comparable to profiles obtained at the $18^{\circ} \mathrm{N}$ study site. Between 50 and $80 \mathrm{~m}$ depth. however, much higher ratios, similar to surface values of the other stations. wer: encountered at Sta. 366.

Primary productivity (Fig. 17) was lower compared to the $18^{\circ} \mathrm{N}$ drift station. The productivity maximum was shallow on the first two days and deepened to a subsurface maximum at $40 \mathrm{~m}$ depth, thus in the upper part of the chlorophyll subsurface maximum. On the last day (Sta. 403), a surface maximum was found again. Productivity followed the depth distribution of chlorophyll as seen from in situ fluorescence and discrete wate: sample analysis. Highest productivity $\left(0.88 \mu \mathrm{g} \mathrm{Cl}{ }^{-1} \mathrm{~h}^{-1}\right)$ was encountered at Sta. 366 (dat)

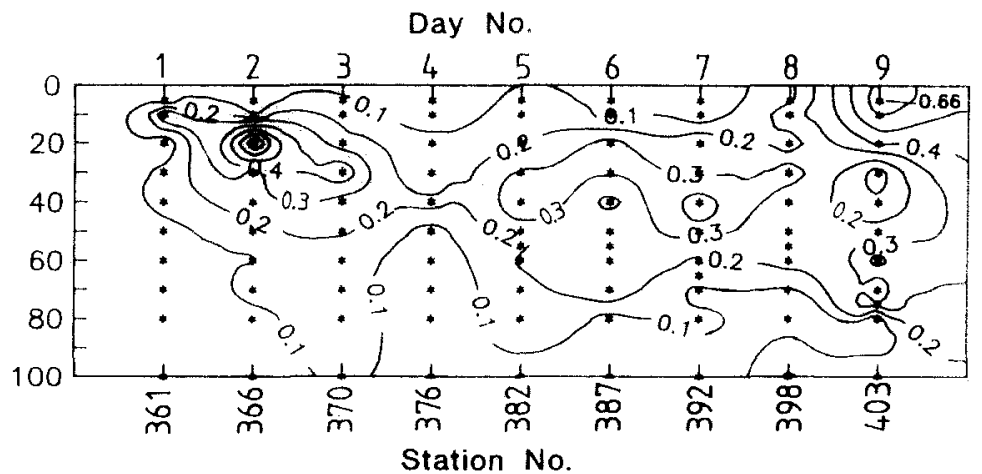

Fig. 17. Primary production $\left(\mu \mathrm{g} \mathrm{Cl}^{-1} \mathrm{~h}^{-1}\right)$ at the $33^{\circ} \mathrm{N}$ study site from $12 \mathrm{~h}$ in situ incubations. 


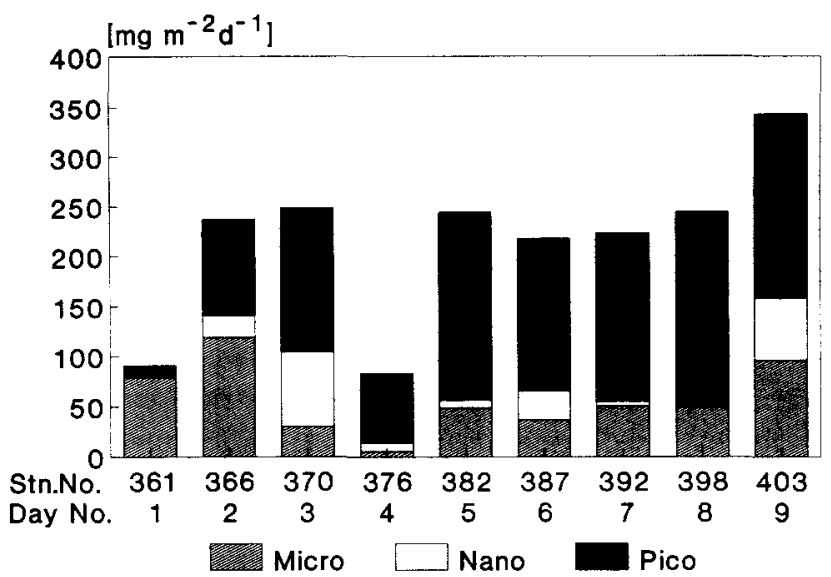

Fig. 18. Size-fractionated integrated primary production $\left(\mathrm{mg} \mathrm{C} \mathrm{m} \mathrm{C}^{-2} \mathrm{day}^{-1}\right), 100 \mathrm{~m}$ water column, at the $33^{\circ} \mathrm{N}$ study site.

2) at $20 \mathrm{~m}$ depth. At $100 \mathrm{~m}$ depth, mostly no carbon uptake could be detected and productivity at the surface was very low, sometimes undetectable (Stas 366, 376, 392).

Integrated primary productivity averaged $0.21 \mathrm{~g} \mathrm{C} \mathrm{m}^{-2}$ day ${ }^{-1}$ (Fig. 18). Stations 361 and 376 were marked by their low productivity $\left(0.09\right.$ and $0.08 \mathrm{~g} \mathrm{C} \mathrm{m}^{-2}$ day $^{-1}$, respectively) and Sta. 403 by its high productivity of $0.35 \mathrm{~g} \mathrm{C} \mathrm{m}^{-2} \mathrm{day}^{-1}$, due to the surface maximum. The decrease of integrated chlorophyll along the track of the drift station could not be observed in productivity measurements.

Except for the first day, $42-86 \%$ of productivity was found in the picoplankton size fraction, with a slight increase over the course of the study. Picoplankton contribution, however, was $<50 \%$ at the depth of highest productivity. Production of microplankton generally was less than $0.1 \mu \mathrm{g} \mathrm{C} \mathrm{l}^{-1} \mathrm{~h}^{-1}$, and that of nanoplankton less than $0.05 \mu \mathrm{g} \mathrm{C} \mathrm{I}^{-1}$ $\mathrm{h}^{-1}$. Only at Sta. 366 at $20 \mathrm{~m}$ depth did microplankton exhibit a high productivity $(0.84 \mu \mathrm{g}$ $\mathrm{Cl}^{-1} \mathrm{~h}^{-1} ; 95 \%$ of total production). Nanoplankton showed higher productivity at Sta. 370 (30 m depth, $0.31 \mu \mathrm{g} \mathrm{C}^{-1} \mathrm{~h}^{-1}$ ). The contribution of both micro- and nanoplankton decreased sharply below $50 \mathrm{~m}$ depth. Chlorophyll maxima of micro- and nanoplankton were not reflected by higher productivity in these size fractions and vice versa.

\section{DISCUSSION}

\section{The tropical North Atlantic at $18^{\circ} \mathrm{N}$}

The biological and chemical properties in the investigation area were highly influenced by variability in the small scale hydrographic regime (PoDEwskr et al., 1993). During the study, different stages of vertical water mass distributions were encountered. Pronounced changes were detected as the drifter passed a frontal structure after day 6 of the 11 days drift station, suggesting biological responses to hydrographic conditions.

A prominent hydrographic feature was the intrusion of Subtropical Salinity Maximum Water $\left(S_{\max }\right)$ into upper pycnocline water that became more pronounced during the course of the study. This water forms at the surface in the inner subtropical gyre due to an imbalance of evaporation/precipitation and sinks down by Ekman pumping (BAUER and 
SiEdLER, 1988). Due to its origin, $S_{\max }$ shows a high oxygen saturation (Worthington. 1976) but nutrient-depletion by phytoplankton growth (KoEve et al., 1993). At the $18^{\circ} \mathrm{N}$ study site, $S_{\max }$ caused low nutrient values within the upper $100 \mathrm{~m}$ water column, best seen in the second half of the study when $S_{\max }$ reached its broadest vertical extension.

Another hydrographic feature encountered after day 6 (Stas 273-287) but also at Sta. 249 (day 3 ) was the low salinity low temperature water mass $\left(S_{\min }\right)$. Originally, this water was the main pycnocline water in "undisturbed" profiles during the first two days. Due to isopycnal mixing on constant density surfaces, $S_{\max }$ intruded into the pycnocline depth horizon, becoming separated into an upper and a lower part, some pycnocline water remaining in between due to interleavings of both water masses, forming $S_{\min }$. Therefore. $S_{\min }$ was characterized by low oxygen saturation and higher nitrate concentrations (KoEve et al., 1993). Due to the deeper $S_{\max }$ water underneath $S_{\min }$, nitrate profiles exhibited the characteristic "nose"-like maximum (Koeve et al., 1993; Podewski et al., 1993).

The direct comparison of in situ fluorescence profiles and chlorophyll measurements from bottle casts occasionally was biased by vertical displacements of the fluorescence maxima even within sampling intervals of $15-20 \mathrm{~min}$, which revealed internal waves with periods of $20 \mathrm{~min}$ to $12 \mathrm{~h}$ and amplitudes of up to $10 \mathrm{~m}$. Both parameters, as a measure of phototrophic biomass, showed subsurface maxima at variable depths (partly due to internal waves) at the nutricline, following the $0.5 \mu \mathrm{mol}^{-1}$ nitrate isoline.

The subsurface chlorophyll maximum is a well known and documented phenomenon of tropical oceans. Both accumulation of phototrophic biomass and an increase in cellular pigment content due to photoadaptation can cause such maxima. There are several reports that subsurface maxima of chlorophyll did not reflect biomass maxima (STEELE, 1964; Beers et al., 1975; Cullen and EPPLeY, 1981; Kimor et al., 1987; TAGUCHI et al., 1988; PIllen, 1989). Profiles of cell numbers of autotrophic picoplankton, particulate organic carbon (POC) and particulate organic nitrogen ( $\mathrm{PON}$ ) proved the chlorophyll maximum at $18^{\circ} \mathrm{N}$ to be also a biomass maximum (Jochem, 1990). Maximum production in the upper half of the chlorophyll maximum, as recently described for subsurface chlorophyll maxima in the oligotrophic central Arabian Sea (Jochem et al., in press), and high values of "new" production (EPPLEY and KoEvE, 1990) prove that this biomass maximum originated from phytoplankton growth rather than sedimentation.

Despite the occurrence of different water masses within the euphotic zone no obvious trend in integrated chlorophyll was discernible. Chlorophyll concentrations were comparable to those found by LENZ et al. (1985) in the vicinity of the study site (Sta. 237 of Biozirkel cruise, R.V. Meteor, March $1983,18^{\circ} 42^{\prime}$ N, $20^{\circ} 07^{\prime} \mathrm{W}$ ), in an almost steady-state oligotrophic epipelagic system in the central Arabian Sea (Jochem et al., in press) and throughout the subtropical and tropical Pacific Ocean (PeÑa et al., 1990). This magnitude of chlorophyll concentrations, thus, can be encountered in wide oceanic oligotrophic regions despite different ecosystem structures. Picoplankton contributed the major part $(75-85 \%)$ of total chlorophyll. During the occurrence of $S_{\min }$, its contribution was somewhat lower but it was still the dominant size fraction.

Cell numbers of picocyanobacteria, eucaryotic picoalgae and autotrophic flagellates 3-5 $\mu \mathrm{m}$ were in the range reported from other oligotrophic oceanic areas (JoINT, 1986; Pillen, 1989). It has been reported from oceanic waters that population maxima of picocyanobacteria were found deeper than those of picoeucaryotes (GLOVER and Morris, 1981; Glover et al., 1985; Murphy and Haugen, 1985; Glover et al., 1988; Chisholm et al., 1988; Li and Wood, 1988; Jochem et al., in press), being attributed to their different 
pigment sets and light absorption efficiencies (Glover and Morris, 1981; Morris and Glover, 1981; Glover et al., 1988). Population maxima of phototrophic picoplankton at the $18^{\circ} \mathrm{N}$ study site occurred shallower than in other oceanic regions (GLOVER and MorRIS, 1981; Glover et al., 1985; Glover et al., 1988; Chisholm et al., 1988; Li and Wood, 1988), i.e. far above the $1 \%$ isolume (KoEve et al., 1993). Due to the fairly low chlorophyll concentrations throughout the whole water column, spectral differences within the chlorophyll maximum layer may have been minor, spectrally different absorption efficiencies having a minor importance.

Abundance ratios of picocyanobacteria to picoeucaryotes were high in the WML, decreasing rapidly below the main pycnocline. At stations with $S_{\max }$ intrusion, an increase of abundance ratios was encountered in the $S_{\max }$ water underlying $S_{\min }$. Due to its near-surface origin, $S_{\max }$ displayed higher abundance ratios compared to $S_{\min }$ that represented the "normal" nutricline water. Lower abundance ratios within $S_{\min }$ therefore were concomitant with the general decrease with depth while $S_{\max }$ caused unexpected higher abundance ratios at greater depths. Recently, GRADINGER and LENZ (1989) showed that picocyanobacteria may be a useful tool in following large scale advective processes.

The contribution of picoplankton $(83-98 \%)$ to total production $\left(0.4-0.45 \mathrm{~g} \mathrm{C} \mathrm{m}^{-2}\right.$ day $^{-1}$ ) was still higher than for chlorophyll, as also for the $33^{\circ} \mathrm{N}$ study site. The only but striking exception was Sta. 279, displaying a pronounced surface maximum. The reason for this different vertical structure and the high production remains enigmatic. EPPLEY and KOEve (1990) and Koeve et al. (1993) showed that the amount of "new" production was well related to the depth of the nutricline. The depth of the nutricline, however, either the primary nutricline or that caused by $S_{\min }$, was not influenced by the $S_{\max }$ intrusion (KoEvE et al., 1993), except on the last day when the nutricline was very deep. Although microplankton production was slightly higher at Sta. 279, its contribution still was almost negligible and much less pronounced as for chlorophyll.

The hydrographic regime had, however, a profound influence on the phytoplankton at Sta. 292, the last day of the drift station. $S_{\min }$ not being present, $S_{\max }$ was found down to about $120 \mathrm{~m}$ and caused fairly low nutrient concentrations throughout the whole euphotic zone. No obvious productivity maximum occurred and the subsurface chlorophyll maximum was only weak. Integrated chlorophyll and productivity were lower compared to $S_{\max } / S_{\min }$ of Stas $273-287$.

The frequent observation of subsurface chlorophyll and productivity maxima near the nutricline in oligotrophic oceans provoked the two layer hypothesis, distinguishing an upper layer (above the subsurface chlorophyll maximum) characterized by a high importance of "regenerated" production sensu DUGDale and GoERING in 1967 and minimum losses by biogenic sedimentation, and the subsurface maximum layer exhibiting relatively higher "new" production and being main source of biogenic particle flux to the deep ocean (Knauer et al., 1984; Small et al., 1987). Recently, Pollehne et al. (in press) and Jochem et al. (in press) presented good evidence for the functioning of this two layer model in the central Arabian Sea and came to the conclusion that it may represent the dynamic equilibrium of an oligotrophic steady-state system.

Dividing the euphotic zone of the $18^{\circ} \mathrm{N}$ study site into the subsurface maximum layer and the "non-maximum" layer above the chlorophyll maximum, generally representing the WML, about two thirds of both autotrophic biomass (measured as Chl $a$ ) and productivity originated from the subsurface maximum layer. Stations influenced by the intrusion of $S_{\max } / S_{\min }$ water showed a lower contribution of the subsurface maximum layer to 
integrated chlorophyll and, more obvious, primary productivity. The ratio of chlorophyll concentration of the subsurface maximum layer to WML of $2: 1$ to $4: 1$ was low compared to ratios of 5:1 to 10:1 in the oligotrophic, nearly steady-state central Arabian Sea (Jochem $e t$ $a l$, in press). In the central Arabian Sea, primary productivity of both layers were fairly comparable; thus, a much lower autotrophic biomass in the upper layer had the same productivity as the higher subsurface maximum biomass, pointing towards a well established and highly efficient microbial loop in the surface layer (JocHEM et al., in press: Pollehne et al., in press). At $18^{\circ} \mathrm{N}$, however, water layer ratios for chlorophyll and primary productivity were similar to each other, which indicates that nutrient and energy cycling in the surface layer was not yet that closely coupled and effective as in the Arabian Sea. The $18^{\circ} \mathrm{N}$ study site system, therefore, can be regarded still far from a steady-state oligotrophic epipelagic system. Further investigations have to clarify whether similar and generally lower ratios for both chlorophyll and primary production are characteristic for the tropical Atlantic Ocean throughout the year or if there is a seasonality in these ratios and the "spring" system of this study was too young for the differently functioning subsystems to have had already developed at the time of the study.

\section{The subtropical Atlantic at $33^{\circ} \mathrm{N}$}

The $33^{\circ} \mathrm{N}$ investigation area was characterized by much weaker vertical gradients of density, no distinct change of water masses being discernible. The main pycnocline, reflecting the depth of winter mixing, was much deeper $(150-200 \mathrm{~m})$. The euphotic zone was even more nutrient-depleted. The nutricline situated at about $60-80 \mathrm{~m}$ depth during the second half of the study showed neither clear relation to hydrographic structures in the upper pycnocline layer nor to the depth of winter mixing and, probably, was determined by biological nutrient uptake.

At the beginning of the drift station, autotrophic biomass tended to show surface maxima. During the course of the study a subsurface maximum evolved at shallower depths compared to the southern study site. Concomitantly, integrated chlorophyll decreased. While highest chlorophyll concentrations $\left(1 \mu \mathrm{g} \mathrm{l}^{-1}\right)$ were similar, integrated chlorophyll was higher than at $18^{\circ} \mathrm{N}$, mainly due to higher concentrations near the surface. The contribution of picoplankton was less than at the southern study site but still $42-53 \%$.

Cell numbers of picocyanobacteria, phototrophic picoeucaryotes and phototrophic flagellates $3-5 \mu \mathrm{m}$ were similar to those at $18^{\circ} \mathrm{N}$. Population maxima of picocyanobacteria occurred much shallower than expected for the open ocean, probably related to the shallow chlorophyll maximum. When a distinct chlorophyll subsurface maximum was present, highest abundances were found in the upper half of the chlorophyll maximum, as described for $18^{\circ} \mathrm{N}$ and other oceanic areas (ITURRIAGA and MITCHELl, 1986; ITURRIAGA and MARRA, 1988; Li and WoOD, 1988; BuRkILl et al., in press; Jochem et al., in press), and population maxima of picoeucaryotes were found below those of picocyanobacteria and at the nutricline, this zonation being known from other oceanic regions as well (GLover and Morris, 1981; Glover et al., 1985; Murphy and HaUgen, 1985; Glover et al., 1988; Chisholm et al., in press). At the start of the drogue study, however, population maxima of picocyanobacteria and picoeucaryotes occurred at about the same depth, as recently described from a post-upwelling system off the coast of Oman, Arabian Sea (Jochem et al. . in press).

Picocyanobacteria dominated autotrophic picoplankton biomass to a greater extent 
compared to $18^{\circ} \mathrm{N}$, reflected by higher abundance ratios as high as 71 . Abundance ratios at Sta. 366 showed significant deviation from the general pattern of decrease with depth in that higher ratios were recorded at $50-80 \mathrm{~m}$; detailed comparison of CTD profiles indicate a slightly warmer $\left(\delta T=0.06^{\circ} \mathrm{C}\right)$ and more saline water in this depth horizon. Hydrographic features and abundance ratios point to the near-surface origin of this water; it was therefore nutrient-depleted and its intrusion resulted in a deeper nutricline. This is again an example of abundance ratios of phototrophic picoplankton being a useful tool in defining water masses.

Corresponding to the depth distribution of chlorophyll, the primary productivity maximum deepened throughout the study period. When subsurface maxima of primary productivity were most pronounced, none or only very low production could be measured both above and below that depth horizon, indicating that the surface layer contained a quite unproductive autotrophic community. At lower latitudes, especially at the bottom of the euphotic zone, high rates of dark $\mathrm{CO}_{2}$ incorporation, namely in the picoplankton size fraction, have been reported (SAIJo and Takesue, 1965; Li et al., 1983; Herbland et al., 1985; TAGUCHI et al., 1988; HARRIS et al., 1989). In their geographic survey of the Pacific and Atlantic Oceans, Prakash et al. (1991) found considerable regions with dark uptake accounting for as much as $30-60 \%$ of light bottle values. Although dark incorporation of $\mathrm{CO}_{2}$ is mostly attributed to heterotrophic processes (LEFTLEY et al., 1983; LEGENDRE et al., 1983), phytoplankton was said to account for $23-76 \%$ of dark $\mathrm{CO}_{2}$ uptake in the Caribbean Sea (TAguchi et al., 1988). From the geographic survey of PRAKash et al. (1991), the $33^{\circ} \mathrm{N}$ study site is situated at latitudes of highest dark uptake and dark to light bottle ratios. The complex question of dark ${ }^{14} \mathrm{CO}_{2}$ uptake is further biased when incubations last longer than a few hours (LI and DickiE, 1991) like in this study. Subtraction of DCMU-bottle incorporation rates (used as dark uptake controls) from light bottle rates may have resulted in "non-discernible" primary production at depths of very low light $\mathrm{CO}_{2}$ uptake at the study site.

With a fairly constant mean of $0.21 \mathrm{~g} \mathrm{C} \mathrm{m}^{-2}$ day ${ }^{-1}$, primary productivity amounted to only about the half of the $18^{\circ} \mathrm{N}$ study site. The contribution of picoplankton was lower compared to the southern study site but still $42-86 \%$ and tended to increase over the course of the study. For both primary productivity and chlorophyll, picoplankton contribution was $<50 \%$ within the depth horizon of highest productivity and chlorophyll. Estimates of "new" production derived from nitrate-uptake measurements of in situ bottle incubations (on the same rig as primary production bottles) were available (EPPLEY and KoEve, 1990). The contribution of "new" to total production was $4-60 \%$ and decreased over the course of the study, pointing towards an increasing nitrate-limitation of "new" production.

\section{Phytoplankton spring blooms in the tropical and subtropical North Atlantic}

At the $18^{\circ} \mathrm{N}$ study site, an oligotrophic epipelagic system typical for the tropical open ocean was encountered. There was no indication for a phytoplankton spring bloom, but a two-layer system displaying subsurface chlorophyll maxima and a predominance of picoplankton. Production/growth of both bacteria and heterotrophic nanoflagellates were grazer-controlled (WEISSE and SCHEFFEL-MöSER, 1991), indicating an established microbial loop. The nutricline was found at the main pycnocline at about $60 \mathrm{~m}$ attributed to winter mixing. Winterly convective mixing is shallow at the study site: Levitus (1982) and 
GLOVER and BREwER (1988) suggest winter mixing down to only $50 \mathrm{~m}$. From the presentation of mean mixed layer depth in February given by RoBINSON et al (1979), winter convective mixing is shallower than $75 \mathrm{~m}$. Winter mixing will mix only the nutrientdepleted part of the water column and will not provide high amounts of new nutrients sufficient to support a phytoplankton spring bloom. An intrusion of Subtropical Salinity Maximum Water $\left(S_{\max }\right)$, as encountered during this study, even increases the depth of the nutricline. Further studies in this area have to show whether hydrographic features found in March/April 1989 are common and have an impact on phytoplankton development and nutrient supply to the euphotic zone, the latter discussed in more detail by KOEVE et al. (1993). Summarizing the picture that evolves from the data obtained during the spring 1989 study, there are some doubts as to the presence of any true phytoplankton spring bloom at $18^{\circ} \mathrm{N}$.

Lower productivity of a higher phototrophic biomass as compared to $18^{\circ} \mathrm{N}$, a higher contribution of larger phytoplankton, about five times higher concentrations of particulate silicate (JoCHEM, 1990), the change of in situ fluorescence, chlorophyll and primary production profiles towards subsurface maxima, decreases of autotrophic biomass, "new" production and $f$-ratios and nutrient depletion within the euphotic zone all suggest that the system encountered at $33^{\circ} \mathrm{N}$ can be seen as a kind of post-spring bloom situation. First results of sediment trap deployments (PASsow and PEINERT, 1993) support this idea. The system encountered could be seen as the first steps towards the establishment of a system of "regenerated" production in the upper water layer and subsurface chlorophyll maxima typical for oligotrophic oceans after the "disturbance" of winter mixing. Mean mixed layer depth at the study site in February is about $150 \mathrm{~m}$ (RoBINSON et al., 1979), agreeing with the recorded depth of the main pycnocline. High spatial and temporal variability but very weak vertical gradients of both hydrographic and biological parameters point towards a "young", not yet very stable epipelagic ecosystem. A differentiation according to the twolayer hypothesis of oligotrophic oceans could not have been established at this time of year; the ratio of chlorophyll of the subsurface maximum layer to the "non-maximum" layer (difficult to define) was $<2: 1$. Production and growth of bacteria and heterotrophic nanoflagellates were rather nutrient/substrate-limited than grazer-controlled (WEISSE and SCHEFFEL-MöSER, 1991). This may reflect the post-bloom substrate-limited system where the microbial loop typical for balanced oligotrophic regions was not yet as developed and closely coupled as compared to $18^{\circ} \mathrm{N}$. Results from the 1989 spring study at $33^{\circ} \mathrm{N}$ give some evidence for a phytoplankton spring bloom occurring at this site that had been missed by the German R.V. Meteor cruise.

Acknowledgements-We thank Captain and crew of R.V. Meteor and all our colleagues involved in the cruise for their efficient help at sea. Measurements of inorganic nutrients by R. Werner. W. Koeve and R. W. Eppley and hydrographic data provided by S. Podewski and G. Saure are greatly appreciated. We are grateful to J. Gunket for help in chlorophyll size fractionation. We thank S. Podewski and W. Koeve for fruitful discussions during the formation of this manuscript and Alain Herbland, John Milliman and an anonymous referee for their helpful comments. This work was funded by grants Ze-119/12-1 by Deutsche Forschungsgemeinschaft and Le-1/63699 by Stiftung Volkswagenwerk.

\section{REFERENCES}

BAUER R. A. and G. SIEDLER (1988) The relative contributions of advection and isopycnal and diapycnal mixing below the subtropical salinity maximum. Deep-Sea Research, 35, 811-837.

Beers J. R., M. H. Reid and G. L. Stewart (1975) Microplankton of the North Pacific central gyre. Populationt structure and abundances, June 1973. Int. Rev. ges. Hydrobiol, 60, 707-737. 
BIENFANG P. K. (1981) Sinking rates of heterogeneous, temperate phytoplankton populations, Journal of Plankton Research, 3, 235-253.

BOAK A. C. and R. Goulder (1983) Bacterioplankton in the diet of the calanoid copepod Eurytemora sp. in the Humber Estuary. Marine Biology, 73, 139-149.

Burkill P. H., R. F. C. Mantoura, C. A. Llewellyn and N. J. P. Owens (1987) Microplankton grazing and selectivity of phytoplankton in coastal waters. Marine Biology, 93, 581-590.

Burkill P. H., R. J. G. Leakey, N. J. P. Owens and R. F. C. Mantoura (in press) Synechococcus and its importance to the microbial foodweb of the northwest Indian Ocean. Deep-Sea Research.

Capriulo G. M. and E. J. Carpenter (1983) Abundance, species composition and feeding impact of tintinnid microzooplankton in central Long Island Sound. Marine Ecology Progress Series, 10, 277-288.

Chisholm S. W., R. J. Olson, E. R. Zettler, R. Goericke, J. B. Waterbury and N. A. Welschmeyer (1988) A novel free-living prochlorophyte abundant in the oceanic euphotic zone. Nature, 334, 340-342.

Corkett C. J. and I. A. MacLaren (1978) The biology of Psuedocalanus. In: Advances in marine biology, F. S. Russell and M. Yonge, editors, New York, pp. 2-231.

Cosper E. and J. C. Stephen (1984) Phytoplankton-zooplankton coupling in the outer continental shelf and slope waters of the mid-Atlantic bight. June 1979. Estuarine and Coastal Shelf Science, 18, 145-155.

Cullen J. J. and R. W. EPpley (1981) Chlorophyll maximum layers of the southern California Bight and possible mechanisms of their formation and maintenance. Oceanologica Acta, 4, 23-32.

Eppley R. W. and W. Koeve (1990) Nitrate use by plankton in the eastern subtropical North Atlantic. March-April 1989. Limnology and Oceanography, 35, 1781-1787.

FenCHEL T. (1987) Ecology of protozoa. Springer, New York, 197 pp.

GARSIDE C. (1982) A chemoluminescent technique for the determination of nanomolar concentrations of nitrate. nitrate and nitrite, or nitrite alone in seawater. Marine Chemistry, 11, 159-167.

GifFord D. J. (1988) Impact of grazing by microzooplankton in the northwest arm of Halifax Harbour. Nova Scotia. Marine Ecology Progress Series, 47, 249-258.

Glover D. M. and P. G. Brewer (1988) Estimates of wintertime mixed layer nutrient concentrations in the North Atlantic. Deep-Sea Research, 35, 1525-1546.

Glover H. E. and I. Morris (1981) Photosynthetic characteristics of coccoid marine cyanobacteria. Archives of Microbiology, 129, 42-46.

Glover H. E., D. A. Phinney and C. S. Yentsch (1985) Photosynthetic characteristics of picoplankton compared with those of larger phytoplankton populations in various water masses in the Gulf of Maine. Biology and Oceanography, 3, 223-248.

Glover H. E., B. B. Prézelin, L. Campbell. M. Wyman and C. Garside (1988) A nitrate-dependent Synechococcus bloom in surface Sargasso Sea water. Nature, 331, 161-163.

Goldman J. C. and D. A. Caron (1985) Experimental studies on an omnivorous microflagellate: implications for grazing and nutrient regeneration in the marine microbial food chain. Deep-Sea Research, 32, 899-915.

Gradinger R. and J. Lenz (1989) Picocyanobacteria in the high Arctic. Marine Ecology Progress Series, 52. 99-101.

Grasshoff K., M. Ehrhardt and K. Kremling (1983) Methods of seawater analysis, 2nd edition. Verlag Chemie, Weinheim.

Harris G. P., F. B. Griffiths and D. P. Thomas (1989) Light and dark uptake and loss of ${ }^{14}$ C: methodological problems with productivity measurements in oceanic waters. Hydrobiologia, 173, 95-105.

Herbland A., A. LeBouteiller and P. Raimbault (1985) Size structure of phytoplankton biomass in the equatorial Atlantic Ocean. Deep-Sea Research, 32, 819-836.

ITURRIAGA R. and J. MARRA (1988) Temporal and spatial variability of chroococcoid cyanobacteria Synechococcus spp. specific growth rates and their contribution to primary production in the Sargasso Sea. Marine Ecology Progress Series, 44, 175-181.

IturRlaga R. and B. G. Mitchell (1986) Chroococcoid cyanobacteria: a significant component in the food web dynamics of the open ocean. Marine Ecology Progress Series, 28, 291-297.

JEFFrey S, W. and G. F. HumPhrey (1975) New spectrophotometric equations for determining chlorophylls a, b, $\mathrm{c}_{1}, \mathrm{c}_{2}$ in higher plants and phytoplankton. Biochem. Physiol. Pfl., 167, 191-194.

Jochem F. (1987) Zur Verbreitung und Bedeutung des autotrophen Ultraplanktons in der Kieler Bucht. Diploma thesis, University Kiel, 127 pp.

Jochem F. (1990) Zur Struktur und Dynamik autotropher Ultraplankton-Gemeinschaften in marinen Warmwasser-Ökosystemen. Ber. Inst. Meereskunde, Kiel, 195, 220 pp. 
Jochem F. J., F. Pollehne and B. Zeitzschel (in press) Productivity regime and phytoplankton size structure in the Arabian Sea. Deep-Sea Research.

Johnson P. W., X. Hual-shu and J. McN. Sieburth (1982) The utilization of chroococcoid cyanobacteria by marine protozooplankters but not by calanoid copepods. Ann. Inst. Océanogr. Paris, 58(S), 297-308.

JoINT I. R. (1986) Physiological ecology of picoplankton in various oceanographic provinces. In: Photosynthetic picoplankton, T. PLATT and W. K. W. LI, editors. Canadian Bulletin of Fisheries and Aquatic Science. 214. 287-309.

Kimor B., Berman T. and A. Schneller (1987) Phytoplankton assemblages in the deep chlorophyll layers off Mediterranean coast of Israel. Journal of Plankton Research, 9, 433-443.

Koeve W., R. W. Eppley, S, Podewski and B. Zeitzschel (1993) An unexpected nitrate distribution in the tropical North Atlantic at $18^{\circ} \mathrm{N}, 30^{\circ} \mathrm{W}$-implications for new production of tropical waters. Deep-Seu Research $I I$, 40, 521-536.

Knauer G. A., J. H. Martin and D. M. Karl (1984) The flux of particulate matter out of the euphotic zone Global Ocean Flux Study, Proc. Workshop U.S. Natl. Acad. 136-150.

LANDRY M. R. and R. P. HASSETT (1982) Estimating the grazing impact of marine microzooplankton. Marine Biology, 67, 283-288.

LANDRY M. R., L. W. HAAs and V. L. Fagerness (1984) Dynamics of microbial plankton communities: experiments in Kaneole Bay, Hawaii. Marine Ecology Progress Series, 16, 127-133.

Leftley J. W., D. J. Bonin and S. Y. Maestrini (1983) Problems in estimating marine phytoplankton growth. productivity and metabolic activity in nature: an overview of methodology. Oceanographic Marine Biological Annual Review, 21, 23-66.

LEGENDRE L. and J. LEFÈvRE (1989) Hydrodynamical singularities as controls of recycled versus export production in oceans. In: Productivity in the ocean: present and past, W. H. BERGER, V. S. SMETACEK and $G$ WEFER, editors, John Wiley, Chichester, pp. 49-63.

Legendre L., S. Demers, C. M. Yentsch and C. S. Yentsch (1983) The ${ }^{14} \mathrm{C}$ method: patterns of dark $\mathrm{CO}$. fixation and DCMU correction to replace the dark bottle. Limnology and Oceanography, 28, 996-1003.

Lenz J., A. Morales and J. Gunket (1993) Mesozooplankton standing stock during the North Atlantic spring bloom study in 1989: a comparison between low, medium and high latitudes. Deep-Sea Research $11,40,559$ 572 .

Lenz J., Schneider G., Elbrächter M., Fritsche P., Johannsen H. and T. Weisse (1985) Hydrographic. chemical and planktological data from the northwest-african upwelling area obtained from February to April 1983 ('Ostatlantik-Biozirkel'): Ber. Inst. Meereskunde, Kiel, 140, 105 pp.

LEvirus S. (1982) Climatological atlas of the world ocean. NOAA/ERL Prof. Pap., Princeton, USA、190 pp.

LI W. K. W. (1986) Experimental approaches to field measurements: methods and interpretation. In: Photosynthetic picoplankton. T. PLATT and W. K. W. LI, editors. Canadian Bulletin of Fisheries and Aquatii Science, 214, 251-286.

LI W. K. W. and P. M. DickIE (1991) Light and dark ${ }^{14} \mathrm{C}$ uptake in dimly-lit oligotrophic waters: relation to bacterial activity. Journal of Plankton Research, 13, (Suppl.), 29-44.

LI W. K. W. and A. M. Wood (1988) Vertical distribution of North Atlantic ultraphytoplankton: analysis by flow cytometry and epiffuorescence microscopy. Deep-Sea Research, 35, 1615-1638.

Li W. K. W., D. V. Subba Rao, W. G. Harrison, J. C. Smith, J. J. Culler, B. Irwin and T. Platt (1983) Autotrophic picoplankton in the tropic ocean. Science, 219, 292-295.

Morris I. and H. E. Glover (1981) Physiology of photosynthesis by marine coccoid cyanobacteria-some ecological implications. Limnology and Oceanography, 26, 957-961.

MuRPhy L. S. and E. M. HaUgen (985) The distribution and abundance of phototrophic ultraplankton in the North Atlantic. Limnology and Oceanography, 30, 47-58.

Passow U. and R. Peinert (1993) The role of plankton in particle flux. Two case studies from the North-East Atlantic Deep-Sea Research $I I, 40,573-585$.

Peinert R., B.v. Bodungen and V. Smetacek (1989) Food web structure and loss rates. In: Productivity in the ocean: present and past, W.H. Berger. V. S. SMETACEK and G. WEFER, editors, John Wiley, Chichester. pp. 35-48.

Peña A. M., M. R. Lewis and W. G. HARRISON (1990) Primary productivity and size structure of phytoplankton biomass on a transect of the equator at $135^{\circ} \mathrm{W}$ in the Pacific Ocean. Deep-Sea Research, 37, 295-315.

Pillen T. (1989) Zur Phytoplanktonverteilung im Roten Meer und Golf von Aden während der 'Meteor"Expedition (MINDIK 5/2) im Frühjahr 1987. Diplom. Univ. Kiel, $149 \mathrm{pp}$.

Podewski S., G. Saure, R. W. Eppley, W: Koeve, R. Peinert and B. Zeitzschel (1993) The nose--a 
characteristic inversion within the salinity maximum water in the tropical North-East Atlantic. Deep-Sea Research $11,40,537-557$.

Pollehne F., A. Klein and B. Zeitzschel (in press) Low light adaptation and export production in the deep chlorophyll maximum layer in the northern Indian Ocean. Deep-Sea Research.

Prakash A., R. W. Sheldon and W. H. Sutcliff JR (1991) Geographic variation of oceanic ${ }^{14} \mathrm{C}$ uptake. Limnology and Oceanography, 36, 30-39.

Rassoulzadegan F. and M. Etienne (1981) Grazing rate of the tintinnid, Stenosomella ventricosa, on the spectrum of naturally occurring particulate matter from the Mediterranean neritic area. Limnology and Oceanography, 26, 258-270.

Rassoulzadegan F., M. Laval-Peuto and R. W. Sheldon (1988) Partitioning of the food ration of marine ciliates between pico- and nanoplankton. Hydrobiologia, 159, 75-88.

Robinson M. K.. R. A. Bauer and E. H. Schroeder (1979) Atlas of North Atlantic-Indian Ocean monthly mean temperatures and mean salinities of the surface layer. U.S. Naval Oceanographic Official Reference Publication, 18, $1339 \mathrm{pp}$.

SaIJo Y. and K. TAKesue (1965) Further studies on the size distribution of photosynthesizing phytoplankton in the Indian Ocean. Journal of the Oceanographical Society of Japan, 20, 264-271.

Small L. F., G. A. Knauer and M. D. Tuel (1987) The role of sinking fecal pellets in stratified euphotic zones. Deep-Sea Research, 34, 1705-1712.

SMetaceK V. (1981) The annual cycle of protozooplankton in the Kiel Bight. Marine Biology, 63, 1-11.

Smetacek V., B.v. Bodungen, B. Knoppers, R. Peinert, F. Pollehne, P. Stegmann and B. Zeitzschel (1984) Seasonal stages characterizing the annual cycle of an inshore pelagic system. Rapp. P.-v. Réun. C. Explor. Mer, 183, 117-140.

Steele J. H. (1964) A study of production in the Gulf of Mexico. Journal of Marine Research, 3, $211-222$.

StEEMANN NiELSEN E. (1952) The use of radioactive carbon $\left(\mathrm{C}^{1+}\right)$ for measuring organic production in the sea. Journal du Conseil International pour Exploration de la Mer, 18, 117-140.

Stramma L. and H.-J. Isemer (1988) Seasonal variability of meridional temperature fluxes in the eastern North Atlantic Ocean. Journal of Marine Research, 46, 281-299.

Strickland J. H. D. and T. R. Parsons (1972) A practical handbook of seawater analysis, 2nd edition. Bulletin of the Fisheries Research Board of Canada $167,310 \mathrm{pp}$.

Taguchi S., G. R. DiTullio and E. A. LAws (1988) Physiological characteristics and production of mixed layer and chlorophyll maximum phytoplankton populations in the Caribbean Sea and western Atlantic Ocean. Deep-Sea Research, 35, 1363-1377.

Venrick E. L. (1978) How many cells to count? In: Phytoplankton manual, A. Sournia, editor, UNESCO, Paris, pp. 167-180.

VERITY P.G. (1985) Grazing, respiration, excretion and growth rates of tintinnids. Limnology and Oceanography, 30, 1268-1282.

WEISSE T. and U. SCHEFFEL-MöSER (1991) Uncoupling the microbial loop: growth and grazing loss rates of bacterial and heterotrophic nanoflagellates in the North Atlantic. Marine Ecology Progress Series, 71, 195205 . 